\author{
RESEARCH ARTICLE \\ 10.1029/2018JB016376 \\ Key Points: \\ - Evidence for 1934 and 1255 AD \\ surface ruptures at Charnath Khola, \\ eastern Nepal \\ - Aggradation pulses at the Charnath \\ Khola follow large surface rupturing \\ earthquakes \\ - Overlooking the predeposit \\ processes of detrital charcoal \\ samples could lead to \\ paleo-earthquake dates older than \\ the actual earthquake dates
}

Supporting Information:

- Supporting Information S1

- Data Set S1

- Data Set S2

- Data Set S3

Correspondence to:

M. Rizza,

rizza@cerege.fr

Citation:

Rizza, M., Bollinger, L., Sapkota, S. N., Tapponnier, P., Klinger, Y., Karakaş, Ç., et al. (2019). Post earthquake aggradation processes to hide surface ruptures in thrust systems: The M8.3, 1934, Bihar-Nepal earthquake ruptures at Charnath Khola (Eastern Nepal). Journal of Geophysical Research: Solid Earth, 124, 9182-9207. https://doi.org/ 10.1029/2018JB016376

Received 12 JUL 2018 Accepted 25 JUN 2019 Accepted article online 2 JUL 2019 Published online 14 AUG 2019

\section{Post Earthquake Aggradation Processes to Hide Surface Ruptures in Thrust Systems: The M8.3, 1934, Bihar-Nepal Earthquake Ruptures at Charnath Khola (Eastern Nepal)}

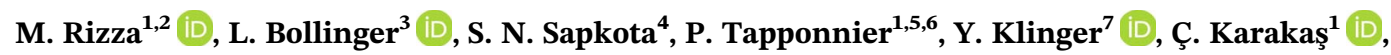 \\ E. Kali ${ }^{1}$, M. Etchebes ${ }^{1}$, D. R. Tiwari ${ }^{4}$, I. Siwakoti ${ }^{4}$, A. Bitri ${ }^{8}$, and S. Bes de Berc ${ }^{8}$ \\ ${ }^{1}$ Earth Observatory of Singapore, Nanyang Technological University, Jurong West, Singapore, ${ }^{2}$ Now at Aix Marseille \\ Univ, CNRS, IRD, Coll France, CEREGE, Aix-en-Provence, France, ${ }^{3}$ CEA, DAM, DIF, Arpajon, France, ${ }^{4}$ Department of \\ Mines and Geology, Lainchaur, Kathmandu, Nepal, ${ }^{5}$ Asian School of the Environment, Nanyang Technological \\ University, Jurong West, Singapore, ${ }^{6}$ Now at the Institute of Crustal Dynamics, China Earthquake Administration, \\ Beijing, China, ${ }^{7}$ Université de Paris, Institut de physique du globe de Paris, CNRS, Paris, France, ${ }^{8}$ Bureau de recherches \\ géologiques et minières (BRGM), Aménagement et risques naturels, Orléans, France
}

\begin{abstract}
The Charnath Khola is a large river crossing the Himalayan thrust system in the region devastated by the great M8.3 1934 Bihar-Nepal earthquake. Fluvial terraces are abandoned along the river and at the base of a 20-m high cumulative thrust escarpment. A trench across the fault scarp exposed Siwalik mudstone/siltstone overthrusting Quaternary units and three colluvial wedges interfingered with fluvial sands. The 85 accelerator mass spectrometry radiocarbon dates, from detrital charcoals sampled in the trench, a river cut and river terraces, constrain the timing of the sedimentary processes following the last two major earthquakes, in 1934 and $1255 \mathrm{CE}$. Although several samples straddle the main earthquake horizon, associating it with the 1934 earthquake, based solely on radiocarbon ages, remains challenging. The 49 detrital charcoal ages found in the pre-earthquake and postearthquake units fall between 65 and $225 \mathrm{BP}$, a period with a flat calibration curve. Many of these radiocarbon ages are suspected to include a part due to inbuilt time (i.e., age of the wood at the time of burning), transport time, and reworking processes, which are difficult to resolve. Considering these ages at their face value could lead to dates older than the actual earthquake dates. We suggest that a part of this chronological bias is also related to a local postseismic aggradation pulse of 4 to $5 \mathrm{~m}$ of sediments, which is documented in the trench and terraces. This fluvial sequence, hiding the most recent surface rupture, is likely related to landslide-sediment deposition triggered by the 1934 Bihar-Nepal earthquake.
\end{abstract}

\section{Introduction}

Although active thrust faults generate geomorphic deformations such as uplifted alluvial surfaces, folding, cumulative topographic scarps, or changes in drainage patterns, paleoseismological investigations alone are often ineffective at identifying past primary surface ruptures along reverse faults (e.g., Lettis et al., 1997). Some of these difficulties might be due to large post event aggradation processes (Korup et al., 2004; Parker et al., 2011) that can bury surface ruptures below fluvial units or scarp-derived colluvium.

The front of the Himalayas is no exception. Indeed, great earthquakes of magnitudes $>8$ have ruptured segments of the Main Frontal thrust (MFT), the largest active thrust fault running along the Himalayan Range. However, the morphological expression of the paleo-ruptures varies along the MFT and recent faulting is not always well preserved, due to high rates of incision and aggradation. In addition, trenches often present a limited amount of age control, making correlation with historical events difficult. Thus, occurrence and spatial extent of surface ruptures for historical earthquakes, including the Mw8.3, 1934, Bihar-Nepal event, remain vividly debated (Bollinger et al., 2014, 2016; Hossler et al., 2016; Lavé et al., 2005; Le Roux-Mallouf et al., 2016; Mugnier et al., 2013; Rajendran et al., 2015; Sapkota et al., 2013; Wesnousky, Kumahara, Chamlagain, Pierce, Karki, et al., 2017; Wesnousky, Kumahara, Chamlagain, Pierce, Reedy, et al., 2017; Wesnousky et al., 2018).

In this paper, we present paleoseismological investigations at the outlet of the Charnath river (hereafter Charnath Khola; Figure 1). This site is located 20-km east of the Ratu-Sir Khola area, where the 1934 AD 


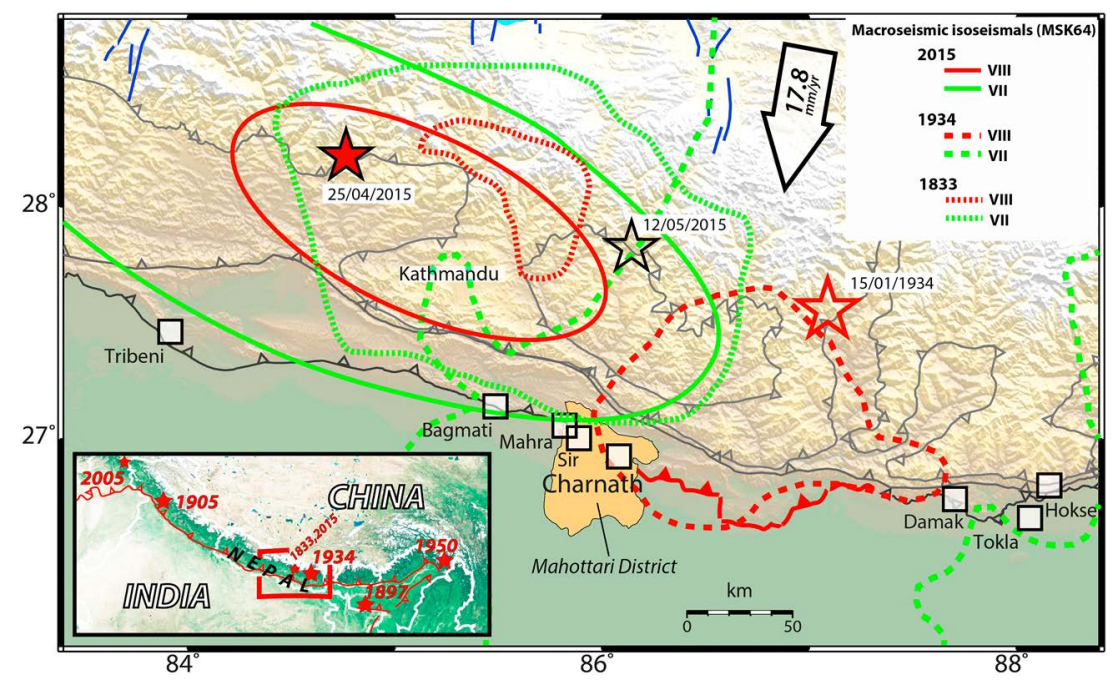

Figure 1. Macroseismic map of the large and great earthquakes in central and eastern Nepal. The instrumental epicenters of the M7.8 Gorkha earthquake that occurred on the 25th of April 2015 and the M7.2 Kodari earthquake of the 12th of May are represented by the black stars (Adhikari et al., 2015). The open red star represents the epicenter of the 1934 Bihar-Nepal earthquake (Molnar and Quidong, 1984). Green and red lines (plain and dashed) represent, respectively, the MSK VII and VIII of the 1833, 1934, and 2015 earthquakes (Ambraseys \& Douglas, 2004; Prajapati et al., 2017), while the thick red toothed polyline marks the minimum stretch of its surface rupture (Sapkota et al., 2013). Black boxes are paleoseismic sites investigated by different research groups along the Main Frontal Thrust (Upreti et al., 2000; Lavé et al., 2005; Sapkota et al., 2013; Bollinger et al., 2014; Wesnousky, Kumahara, Chamlagain, Pierce, Karki, et al., 2017; Wesnousky, Kumahara, Chamlagain, Pierce, Reedy, et al., 2017). The limits of the Mahottari district (see Table 1 and text) are highlighted in orange color. Open arrows reflect shortening rates across the Himalayan range (Ader et al., 2012). Onset map with large and great earthquakes along the Main Himalayan thrust, since 1830.

earthquake had previously been documented (Bollinger et al., 2014; Sapkota et al., 2013). The Charnath site was selected because it shows a distinct fault scarp within the zone of strongest shaking during the 1934 earthquake (Figure 1). In addition, this site presents a suite of nested fluvial terraces in the hanging wall of the MFT, allowing confrontations between terrace uplift, river incision, and earthquake deformation.

The 69 detrital charcoal samples from the trench, 3 samples from a river cut, and 13 samples collected in pits dug in uplifted terraces were dated by accelerator mass spectrometry (AMS) to determine the timing of past surface-rupturing earthquakes at this site. Our observations confirm that at least one major earthquake ruptured the surface with a large vertical coseismic slip at the Charnath. We further discuss some methodological chronological issues related to possible inheritance in radiocarbon ages that may reflect complex fluvial transport histories.

\section{Seismotectonic Setting}

\subsection{Historical Chronicles of Large Earthquakes in Central and Eastern Nepal}

Large historical earthquakes $(M>7.5)$ have been reported since medieval times along the Himalayan front, in central and eastern Nepal (e.g., Bollinger et al., 2014, 2016; Bilham , 2019; Molnar \& Pandey, 1989; Pant, 2002; Table 1 and Figure 1). The latest of these earthquakes is the blind $M w 7.8$ Gorkha earthquake that affected Central Nepal on 25 April 2015, partially rupturing a locked segment of the Main Himalayan Thrust fault, the plate boundary between India and the Himalayan Range (Avouac et al., 2015; Grandin et al., 2015). In the Mahotarri district, where the Charnath site is located, the macroseismic intensities associated with the 2015 event were as high as VI (Martin et al., 2015). A few years before, on the 20th of August 1988, a blind $M w 6.7$ earthquake had already strongly affected the area (Intensity VII; Dixit et al., 1991), killing more than 700 persons.

Yet stronger was the $M w 8.3$ Bihar-Nepal earthquake that struck on the 15th of January 1934 (Figure 1). This earthquake devastated a large area of central and eastern Nepal. The mesoseismal area with intensities $\geq$ VIII, covered more than $10,000 \mathrm{~km}^{2}$ (Ambraseys \& Douglas, 2004; Sapkota et al., 2013, 2016). The 
Table 1

Historical Earthquakes Reported for Central and Eastern Nepal and Their Effects in the Mahottari District (Where the Charnath Site Lies) With Their Instrumental or Macroseismic Magnitudes

\begin{tabular}{|c|c|c|c|c|c|}
\hline Earthquake Date & $\begin{array}{l}\text { Magnitude ( } M w \\
\text { or } M w \text { macro) }\end{array}$ & $\begin{array}{l}\text { Macroseismic intensity } \\
\text { estimated in the } \\
\text { Mahottari district }\end{array}$ & $\begin{array}{l}\text { Significant macroseismic } \\
\text { effects in the } \\
\text { Mahottari district }\end{array}$ & References & General notes \\
\hline 25 April 2015 & $M w 7.8$ & VI & No effects reported & Martin et al. (2015) & $\begin{array}{l}\text { Rupture stopped halfway } \\
\text { along the locked fault zone. }\end{array}$ \\
\hline 21 August 1988 & $M w 6.7$ & VII & $\begin{array}{l}\text { Charnath zone affected } \\
\text { by sand boils }\end{array}$ & Dixit (1991) & $\begin{array}{l}\text { Hypocenter located at a depth } \\
\text { of } 57 \mathrm{~km} \text {. No surface ruptures. }\end{array}$ \\
\hline 15 January 1934 & $M w 8.3$ & $\geq$ VIII & $\begin{array}{l}\text { The Mahottari district } \\
\text { was the worst affected } \\
\text { of all Terai districts } \\
\text { along the strike (1) }\end{array}$ & $\begin{array}{l}\text { Rana (1935) } \\
\text { Roy (1939) }\end{array}$ & $\begin{array}{l}\text { The tremors were very strong } \\
\text { in the districts of Jaleshwar } \\
\text { and Hanumannagar. "The } \\
\text { land was split wide open in } \\
\text { many places (especially in } \\
\text { Hanumannagar and } \\
\text { Jaleshwar). Some people } \\
\text { lost their goods in these } \\
\text { holes. Water gushed out of } \\
\text { these holes and inundated } \\
\text { the fields and pathways } \\
\text { for } 2 \text { or } 3 \text { days." Effect } \\
\text { in Katmandu. }\end{array}$ \\
\hline 23 May 1866 & Mwm $7.2 \pm 0.2$ & Probably VI & Not reported & $\begin{array}{l}\text { Szeliga et al. (2010), } \\
\text { Martin and Szeliga (2010), } \\
\text { and Martin et al., 2015, } \\
\text { referred in Oldham (1883) }\end{array}$ & $\begin{array}{l}\text { Not reported in Rana (1935). } \\
\text { Followed by a severe } \\
\text { shock in Kathmandu in } \\
\text { September. }\end{array}$ \\
\hline 26 August 1833 & $\begin{array}{l}\text { Mwm } 7.3 \pm 0.1 \\
\text { Mwm } 7.7 \pm 0.2\end{array}$ & $\begin{array}{l}\text { VI at Chisapani, } \\
5 \mathrm{~km} \text { from } \\
\text { Charnath Khola }\end{array}$ & $\begin{array}{l}\text { Yes. Intensity EMS VI } \\
\text { reported by Martin } \\
\text { and Szeliga (2010) }\end{array}$ & $\begin{array}{l}\text { Szeliga et al. (2010), } \\
\text { Ambraseys and Douglas } \\
\text { (2004) Martin and } \\
\text { Szeliga (2010), } \\
\text { Campbell (1833), Bilham } \\
\text { (1995), Martin and } \\
\text { Szeliga (2010), Martin } \\
\text { et al. (2015), and Bilham } \\
\text { and Wallace (2005) }\end{array}$ & \\
\hline 4 June 1808 & $\begin{array}{r}\text { Estimated at } \\
\text { Mmax 6-7 }\end{array}$ & Not reported & Not reported & $\begin{array}{l}\text { Oldham (1883), Pant (2002), } \\
\text { and Martin and Szeliga } \\
(2010)\end{array}$ & $\begin{array}{l}\text { Houses collapsed in } \\
\text { Kathmandu. However, } \\
\text { effects in central Nepal were } \\
\text { lighter than in } 1833 \text { AD. Felt } \\
\text { at 2:40 p.m. in Banda and } \\
\text { Dinagepore Intensity IV in } \\
\text { Banda-Bahraich } \\
\left(81.59^{\circ} \mathrm{E}, 27.57^{\circ} \mathrm{N}\right)\end{array}$ \\
\hline 15 May 1680 & $\begin{array}{l}\text { Estimated at } \\
\text { Mmax }<7.5\end{array}$ & Not reported & Not reported & Rana (1935) & $\begin{array}{l}\text { Many buildings destroyed } \\
\text { in Kathmandu }\end{array}$ \\
\hline 14 September 1344 & $\begin{array}{l}\text { Estimated at } \\
\text { Mmax 7-8 }\end{array}$ & Not reported & Not reported & Pant (2002) & $\begin{array}{l}\text { Fatally wounded King } \\
\text { Ari Malla }\end{array}$ \\
\hline 7 June 1255 & Estimated at M8 & Not reported & Not reported & Pant (2002) & $\begin{array}{l}\text { Temples and houses collapsed } \\
\text { killing one third of the } \\
\text { Kathmnandu valley's } \\
\text { inhabitants. Killed King } \\
\text { Abhaya Malladeva. }\end{array}$ \\
\hline 24 December 1223 & Unknown & Not reported & Not reported & Pant, 2002 & \\
\hline
\end{tabular}

Note. Notes on the 1934 macroseismic effects in the Nepalese Terai, with a focus on the effects reported nearby Charnath (Mahottari district of Nepal). "Due to the earthquake on 15 January, cracks appeared in the Bada Hakim's house, and the house of the Assistant Subba was destroyed to the foundation. The temples of Ramchandra and Janaki at Janakpur were intact. The houses of the mahants (priests) were destroyed to the foundation and four or five persons were buried in the debris but no personal harm was done. Five women and children were killed in the wreckage of pukki buildings at Janakpur. When the jail broke down, prisoners escaped and could not be tracked up to now. A report was made about the escapade on 18 January." "Although the earthquake hit the Terai hard, the losses of lives were fortunately low. The reason is that $90^{\circ}$ of the houses were small and made of wood or bamboo. These houses did not collapse like those made of bricks or stone." "Amounts, as mentioned below, were sanctioned soon after the earthquake to repair government buildings, dharma-bhakaris and wells, as well as to provide relief to the poor people in Terai: Birjunj 10100.00, Saptari Siraha 10100.00, Mahottari Sarlahi 17700.00, Morang Biratnagar 5100.00, Jhapa 1600.00, Chitwan 225.00, [... .], total 52725.00.” 
Charnath site lies at its southwestern end (Figure 1). The Mahottari district was very severely affected (Rana, 1935, Williamson in Roy, 1939). Chronicles also report triggered landslides along much of eastern Nepal. Liquefaction and slumping affected a 300-km long region farther south in Bihar.

A few earlier earthquakes in central and eastern Nepal are also documented in chronicles. On the 23rd of May 1866, Kathmandu was strongly shaken by a moderate earthquake. This event followed after 33 years the large earthquake that struck on the 26th of August 1833, a significant event often compared to the 2015 Gorkha earthquake (e.g., Martin et al., 2015).

Some earlier earthquakes were chronicled in Kathmandu, although they remain poorly documented spatially. On 4 June 1808, an earthquake affected the Kathmandu valley, but the effects where much less than those reported for the 1833 earthquake (Martin \& Szeliga, 2010; Pant, 2002). A destructive earthquake occurred in 1680, during the chronicle-rich Mughal period. Its magnitude is estimated to be lower than Mw 7.5 because this earthquake was only reported within the limited area of the Kathmandu valley (Bollinger et al., 2016). Finally, three medieval earthquakes were reported in contemporaneous sources written during the fourteenth and thirteenth century (Pant, 2002). The 1344 earthquake happened around midday on the 14th of September and fatally wounded King Ari Malla, who died the following day. The earthquake of 7 June 1255 was a major earthquake, as the chronicles specify that temples and houses collapsed, killing one third of the valley's inhabitants including King Abhaya Malladeva. The 1223 event, which is the earliest event known from a primary source, occurred on the 24th of December, but it is not associated with any observations.

\subsection{Previous Work}

The historical chronicles have been complemented by paleoseismic studies. Several of these studies only identified one event during the past 1,000 years, with no surface ruptures linked to any twentieth century earthquake (Kumar et al., 2006, 2010; Lavé et al., 2005; Malik et al, 2010, Wesnousky, Kumahara, Chamlagain, Pierce, Karki, et al., 2017). However, other recent paleoseismological investigations at the Sir Khola (Figure 1) identified a surface rupture associated with a large coseismic slip after $1660 \mathrm{AD}$, likely to be related to the 1934 Bihar-Nepal earthquake. Complementary paleoseismic observations at the Sir Khola have shown that the historical $1255 \mathrm{AD}$ earthquake may also have produced a surface rupture at the same site (Bollinger et al., 2014; Sapkota et al., 2013).

To date, these results remain disputed, as recent contradicting interpretations have been proposed for the Sir Khola (Wesnousky et al., 2018). In addition, independent trenches excavated at Mahra Khola (Figure 1), to the West of the Sir Khola, farther from the 1934 mesoseismal area, might reveal a different history of earthquakes. There, a trench excavated across a young fault scarp showed evidence of a 17-m slip during a medieval earthquake, which is not referenced in any historical chronicle ( 1100 AD; Lavé et al., 2005). Conversely, the 1934 surface rupture is not yet recognized at the Mahra Khola nor further West in Bagmati (Wesnousky, Kumahara, Chamlagain, Pierce, Karki, et al., 2017; Figure 1).

Eastward, toward the mesoseismal area of the great 1934 earthquake, several sites exhibit staircases of Holocene terraces and morphotectonic signatures of active faulting (Figure 1; Bollinger et al., 2014; Delcailleau, 1992; Lavé et al., 2005; Nakata, 1989; Sapkota, 2011; Sapkota et al., 2013). Immediately to the East of the Sir Khola, at the outlet of the Ratu river (in Tulsichauda), Bollinger et al. (2014) proposed that the upward growth of a low terrace level is related to the vertical coseismic slips of the great 1934 and $1255 \mathrm{AD}$ earthquakes, and they related abandoned older terrace levels to six or seven earthquakes during the past 4,500 years. The Holocene apparent uplift rate in the Ratu/Sir area is $\sim 10-20 \mathrm{~mm} /$ year (Bollinger et al., 2014), a value consistent at first order with the Holocene shortening rate of $\sim 21 \mathrm{~mm} / \mathrm{year}$ at Bagmati (Lavé \& Avouac, 2000).

\subsection{The Main Frontal Thrust at Charnath Khola} 2.3.1. Morphological Observations

The Charnath Khola crosses the MFT at Tintale, a village built on a fluvial terrace (Figures 2, 3, and 4a). The active thrust of the MFT brings folded and faulted Siwalik sandstones and conglomerates on top of the foreland alluvial sediments. The most prominent trace of this thrust is marked by a 20-m high topographic scarp, which can be followed along both banks of the river (Figure 4; see Figure 2 for location of photos). However, the fault plane itself is not exposed, even along river cuts (Figures $4 \mathrm{~b}$ and 5). 


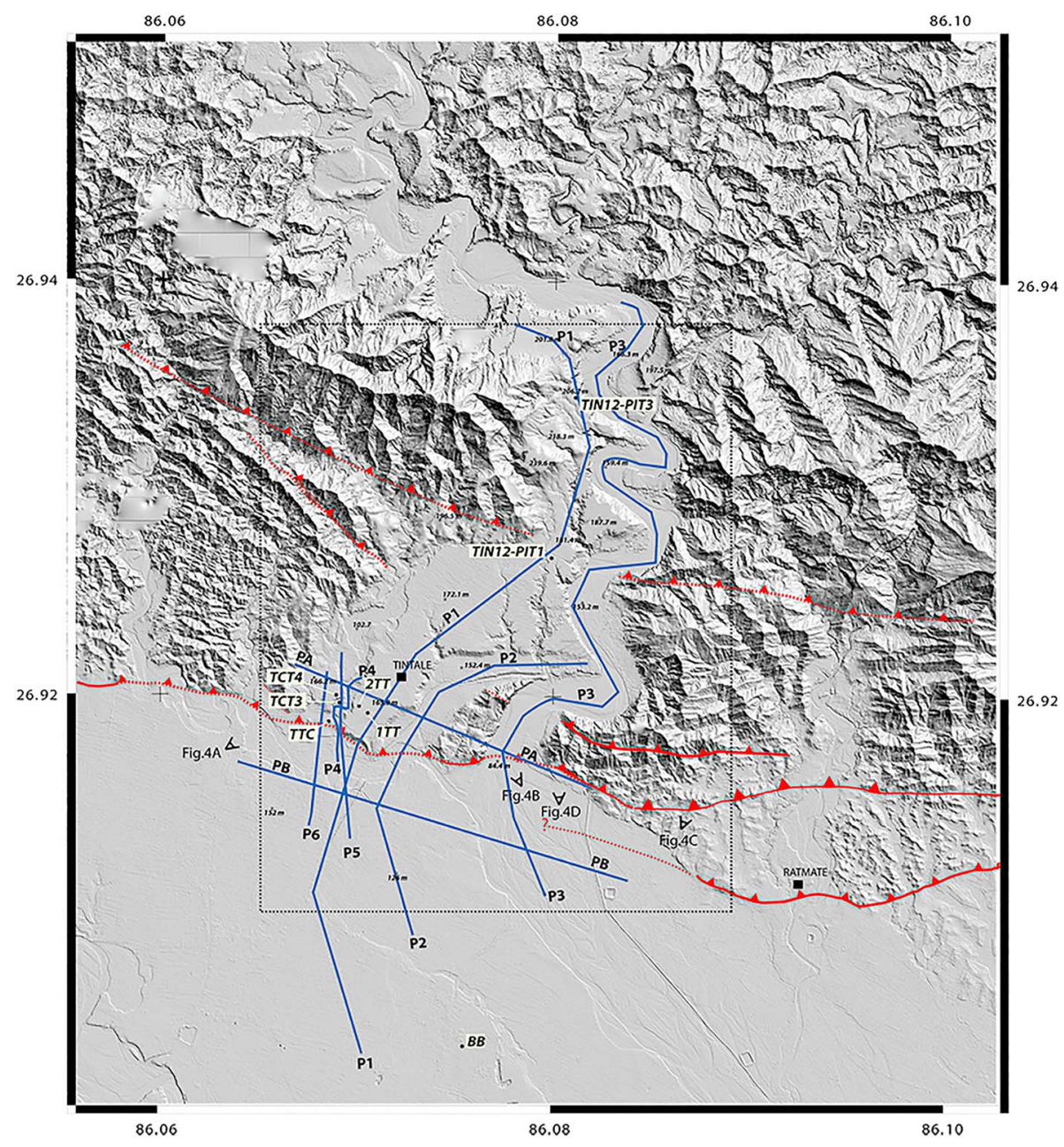

Figure 2. Grey shaded topography from a Digital Elevation Model acquired with an Airborne Lidar survey (resolution of $1 \mathrm{~m}$ ) around the Charnath site. Coordinates are in WGS 84. The red lines represent the thrust faults mapped along the front of the range. Black dots and associated labels in white boxes represent the ${ }^{14} \mathrm{C}$ sampling pit locations. Topographic profiles are represented by blue lines and are presented in Figure 11. The black dashed box represents the inset of Figure 3.

In the hanging wall of the frontal thrust, uplifted strath terraces of the Charnath River are carved in the north dipping upper Siwalik beds (Figures 3 and $4 \mathrm{~b}$ ). These terraces are capped by pebble-gravels and sands. In the footwall, modern fluvial sands and pebbles form the riverbed of the Charnath Khola and its tributaries. West of the modern Charnath Khola, we mapped several large remnants of terrace treads (Figures 3, 4a, and 4b), similar to what has been described at the Bagmati or Ratu Khola (Lavé \& Avouac, 2000; Bollinger et al., 2014). On the eastern side of the Charnath Khola, no terrace remnants were found in the badland morphology of the sheared Siwaliks (Figures 4c and 4d). A 1- to 3-m high scarplet (Figures $4 \mathrm{e}$ and 6) develops at the toe of the south facing, 15- to 20-m high, cumulative escarpment.

Further east, the frontal escarpment corresponds to the southern slope of a ridge exposing Siwalik sandstones (Figure 4c) that we interpret as a fold related to frontal thrusting. It extends perpendicular to the main drainage for at least $1 \mathrm{~km}$, up to a right-stepping strand of the front.

\subsubsection{Preliminary Paleoseismic Observations Along a River Cut}

At Tintale Creek, a river cut on the eastern side of the Saphi Khola (Figures 2 and 5) exposes strath terrace carved into buff-colored microconglomerates and sandstones with interbedded grey clay layers (Figure $5 b$ ). The terrace is capped with gravels, standing $\sim 11 \mathrm{~m}$ above the riverbed (Figure 5a). The Siwalik outcrop is likely overturned, given the inverted graded bedding. It dips at $35^{\circ}-40^{\circ}$ to the north. It is affected by a complex network of faults and fractures, with the net offset of these faults decreasing toward the north. 


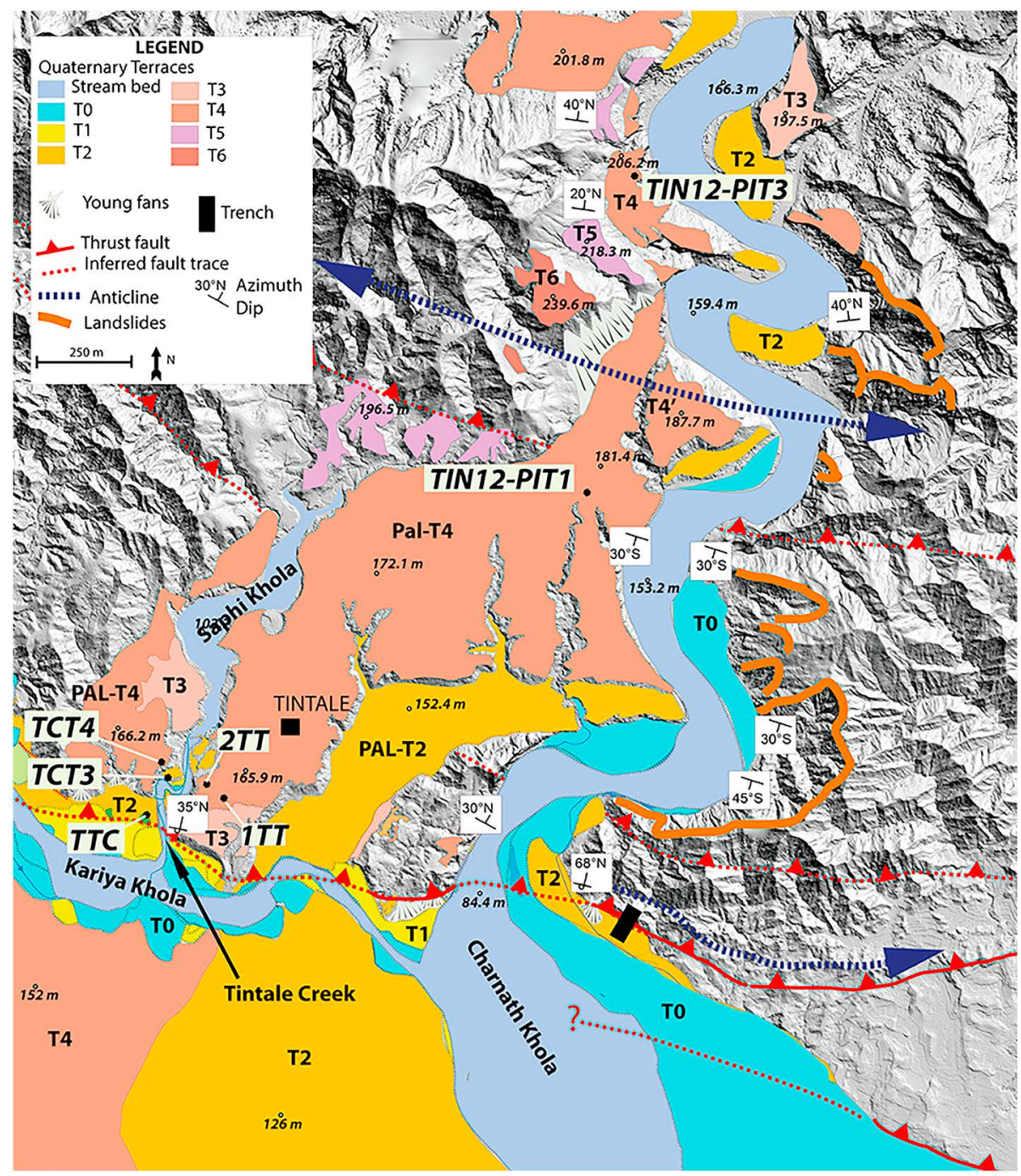

Figure 3. Geomorphic and neotectonic map of Quaternary fluvial terraces at the outlet of Charnath Khola on top of the Lidar shaded topography. See text for discussion and relative elevations. The red lines are mapped faults and the black box is the location of the Cobra paleoseismic trench.

The Siwalik beds are offset by two thrust faults dipping to the north, which are in turn crosscut by a network of normal faults dipping $40^{\circ}-60^{\circ}$ to the south. The frontal fault scarp has been eroded and the main fault is not exposed. Instead, it is now covered by a 3- to 5 - $\mathrm{m}$ thick sequence of wedges interfingered with fluvial sands abutting on the Siwaliks (Figure 5c). These wedges are composed of loose Siwalik blocks mixed with cobbles and pebbles derived from capping fluvial material falling from the scarp. Two detrital charcoal fragments (TC09-07 and 08) were collected within one of the colluvial wedges that yielded calibrated ages ranging from 1644 to 1955 AD (Table 2). A charcoal piece (TC09-I03) collected 1-m below the top surface yielded a modern age of $1963 \mathrm{AD}$. This latter age suggests a recent entrenchment of the Saphi Khola into the scarp deposits.

\section{Paleoseismic Observations at the Cobra Trench}

The fault segment located immediately to the east of the Charnath Khola is characterized by a large topographic scarp, with modern alluvial sediments at its toe, and a small break in slope at its base, which suggests a recent surface rupture. Thus, we excavated a 70-m long, 5-m wide, and 8- to 10-m deep trench (Figures 3, 4, and 6) across the scarp, into $\mathrm{T}_{2}$ (Figures 2 and 6). Unconsolidated material in the footwall of the MFT 

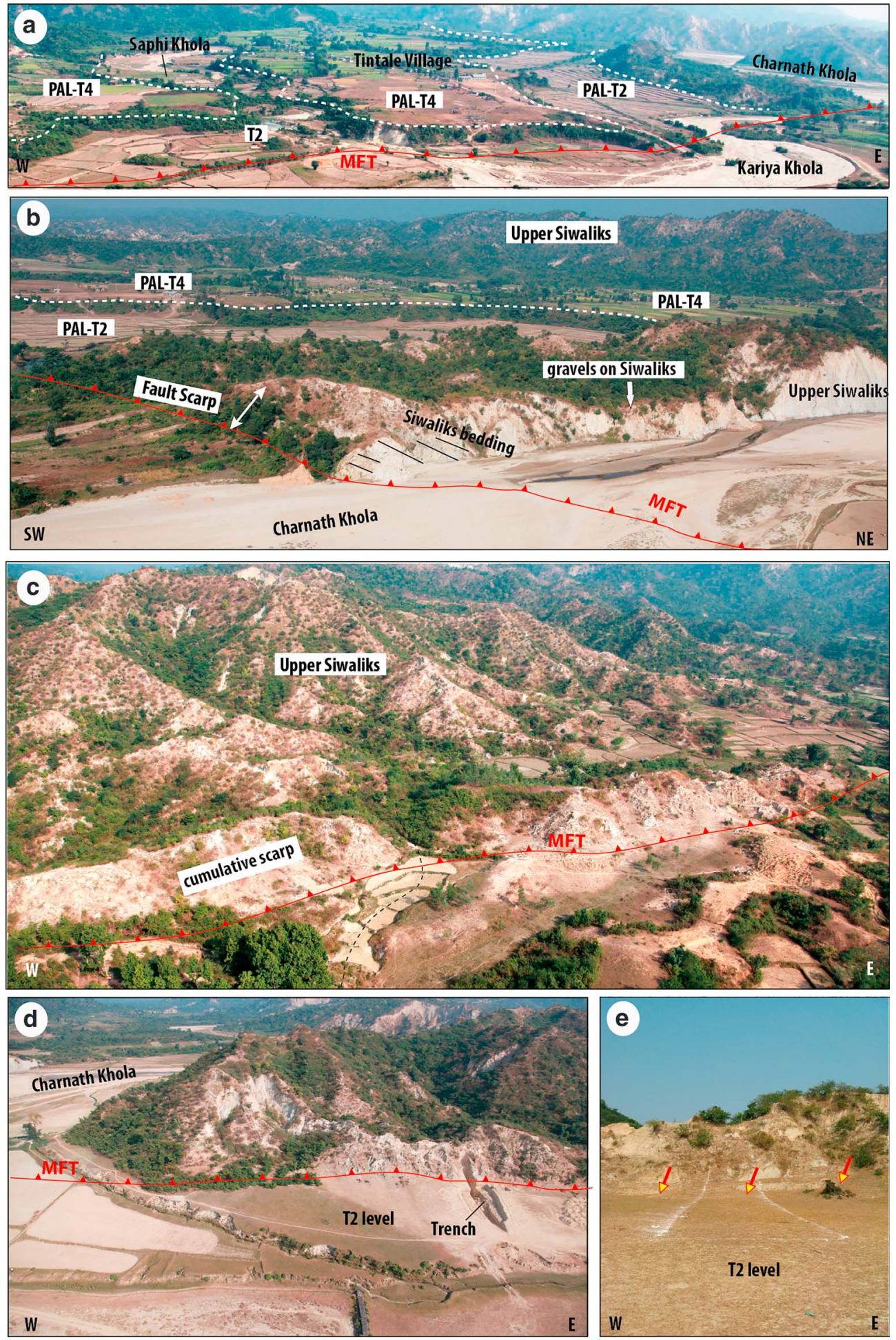

Figure 4. Helicopter views (taken on the 2nd of December 2009) of the cumulated fault scarp along the Charnath Khola MFT strand (see location in Figure 2). The red line represents the assumed trace of the MFT. (a) View on Paleomeander Pal-T4 and Pal-T2 at the confluence of the Saphi, Kariya and Charnath Khola (Tintale Creek). The white dashed lines highlight the alluvial levels. (b) The outlet of the Charnath Khola (river cut) where the MFT (in red) cuts the present-day riverbed. The white dashed line represents the top of the Pal-T4 level. (c) A 20- to 30-m high cumulative scarp east of the outlet of the Charnath Khola. (d) Helicopter view toward the north of the Front Range after the Cobra trench excavation. (e) Field view taken before the excavation. The red and yellow arrows locate the 1-m high scarp at the toe of the cumulative scarp. The white line on the photo delimits the location of the future trench. 

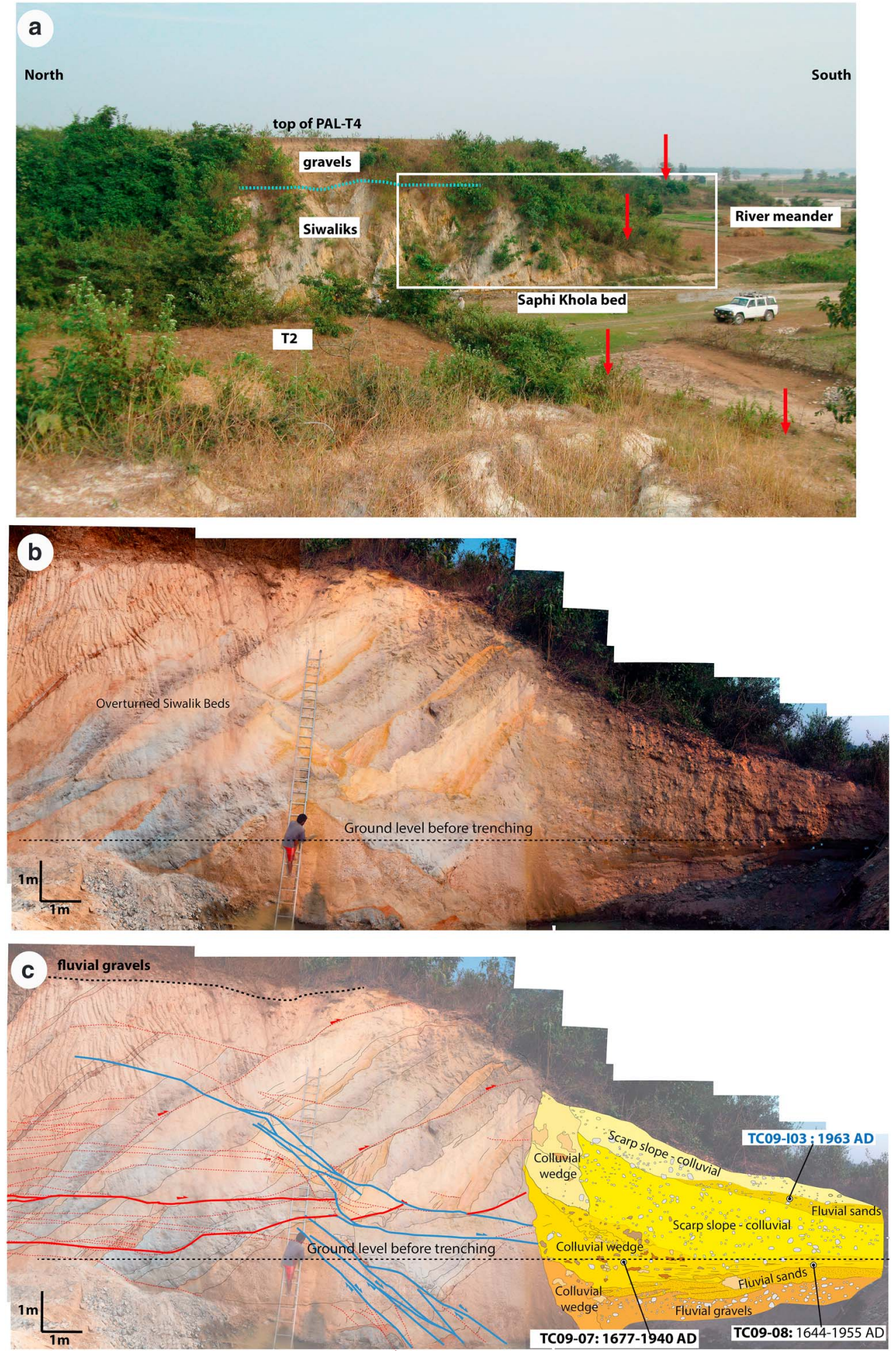

Figure 5. (a) Field view of the natural river cut at the Tintale Creek site (see location in Figure 3) taken in December 2009 before excavation. The white box represents the refreshed section of the river cut presented in $b$ and $c$. The red arrows indicate the expected position of the MFT and the blue dashed line represents the boundary between the Siwaliks and the gravels of Pal-T4. (b) Photomosaic of the refreshed river cut with position of the ground level (dashed black line) of the Saphi Khola before excavation. (c) Paleoseismic interpretations and position of the charcoal samples. 

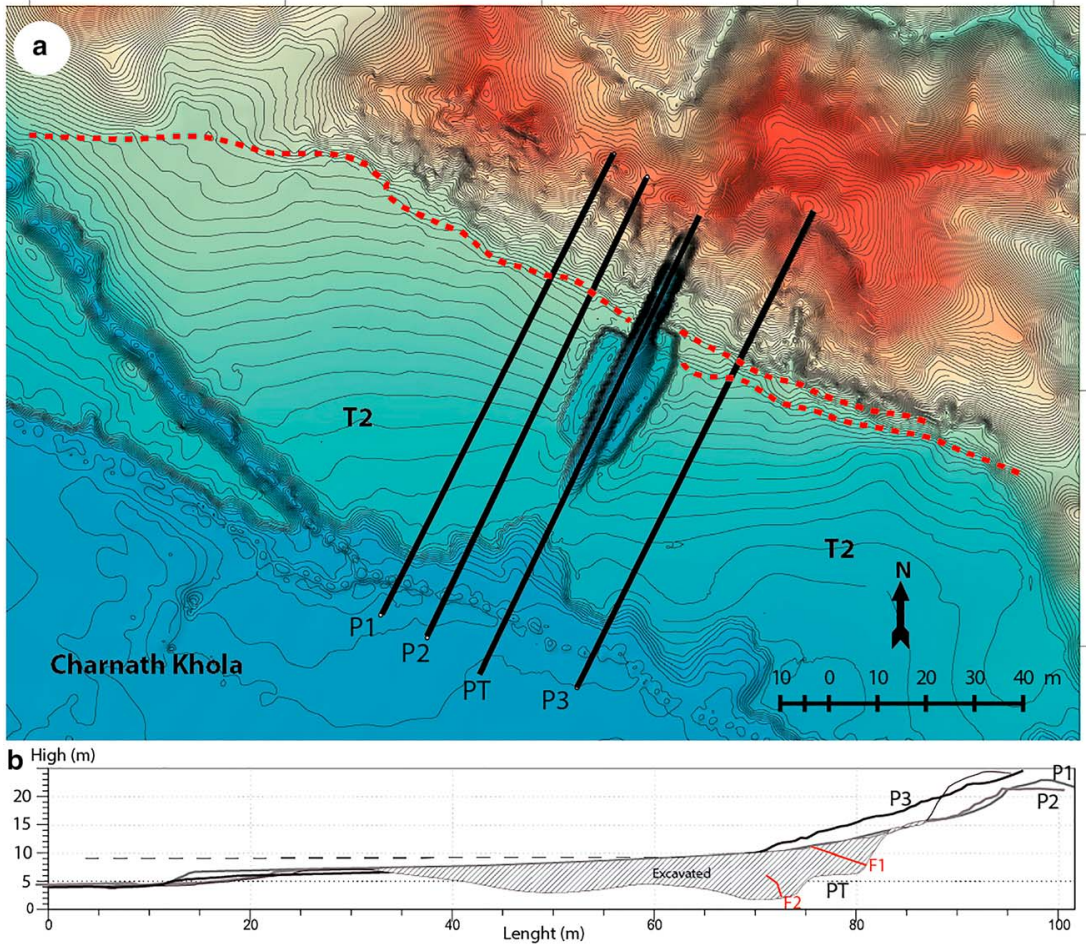

Figure 6. (a) Total Station Digital Elevation Model in the vicinity of the trench, with contour lines every $20 \mathrm{~cm}$. Black lines represent the topographic profiles represented in Figure $6 \mathrm{~b}$. The red dashed line is for the assumed trace of the MFT. (b) Elevation profiles across the cumulative scarp. Hatches mark the excavation trace. The red lines indicate the major fault zones F1 and F2 further mapped in Figure 7.

required excavating benches after a partial collapse of the south-eastern section. Trench logs are reported in Figure 7 and supporting information Figure S1.

\subsection{Description of Stratigraphic Units}

The uppermost unit found in the trench is composed of light-colored siltstones and darker mudstones from Siwalik formations dipping northward between $55^{\circ}$ and $70^{\circ}(S W 1$ in Figures 7 and 8). This upper unit differs from the lower Siwaliks, which are characterized by white siltstones (SW2 in Figures 7 and 8). These units are part of the middle Siwalik sequence that outcrops along the most frontal antiform, which is more than 20-km long (Pradhan et al., 2004). A sequence of buff-colored and reddish alluvium units (u7-u8-u9) is stacked between the two units SW1 and SW2. The conglomerates (u9) incorporate rounded pebbles and reddish gravels in a coarse matrix. It unconformably overlies Siwalik Unit SW2. Some material of Unit u9 fills an open fissure on the east wall (Figure 7). Unit u8 consists of indurated fluvial sand and silt deposits with few pebbles. Included in $\mathrm{u} 8$, a white-colored silty layer is pinched and drag-folded, which is particularly visible on the eastern wall (meter mark 6 in Figure 7 and visible in Figure 8a). A thick layer of oxidized gravels and pebbles ( $\mathrm{u} 7$ ) lies above the $F 1$ fault zone (Figure 7). The top of $\mathrm{u} 7$ is characterized by an erosional contact (former fluvial channel) with coarse sands (u1).

The southern part of the trench exposes massive, unsorted deposits interbedded with unconsolidated fluvial sands. At the base of the trench, a loose conglomeratic fluvial unit with rounded pebbles and cobbles (u5) is topped by stratified and laminated coarse-to-fine sand mixed with fluvial pebbles (u4). Some conglomeratic beds occurring as channel-filled deposits are also visible in u5. On top of Unit $\mathrm{u} 4$ is a brownish massive deposit (CW2), 2-m thick and 4-m long, formed by large chunks of dark Siwalik bedrock and few oxidized pebbles, embedded in an unsorted well-indurated alluvial sandy matrix. CW2 and Siwalik Block SW2 have a sharp vertical contact, while the toe of CW2 is interfingered with finely laminated sands interbedded with light-colored clays (u3). A red-colored kiln was found in Unit $\mathrm{u} 3$ in the east wall (see meter mark 19 in Figures 7 and $8 \mathrm{~b}$ ), which is a good stratigraphic marker of ground surface. An erosional unconformity on both walls truncates the top of $\mathrm{CW}$ 2, Siwalik Unit Sw2, Unit u8, and Unit u9. On the western wall the 
Table 2

AMS Radiocarbon $\left({ }^{14} \mathrm{C}\right)$ Dates From Detrital Charcoals Collected in the Charnath Trench and Tintale Creek

\begin{tabular}{|c|c|c|c|c|c|c|}
\hline \multirow[b]{2}{*}{ Unit $^{\mathrm{a}}$} & \multirow{2}{*}{$\begin{array}{l}\text { Sample } \\
\text { number }\end{array}$} & \multirow{2}{*}{$\begin{array}{l}\text { Measured radiocarbon } \\
\text { age (years BP) }\end{array}$} & \multirow{2}{*}{$\begin{array}{c}\text { Uncertainties radiocarbon } \\
\text { age (years BP) }\end{array}$} & \multirow{2}{*}{$\begin{array}{l}\delta^{13} \mathrm{C} \\
\text { value }^{\mathrm{c}}\end{array}$} & \multicolumn{2}{|c|}{ Calibrated ages (calendric, $2 \sigma)^{\mathrm{d}}$} \\
\hline & & & & & From & To \\
\hline U8 & C009-07 & 7,950 & 30 & -28.2 & BC 7031 & BC 6699 \\
\hline U8 & C009-09 & 8,030 & 30 & -29.0 & BC 7066 & BC 6827 \\
\hline CW1-a & C009-11 & 215 & 30 & -11.8 & AD 1644 & AD 1955 \\
\hline U8 & C009-20 & 8,050 & 30 & -28.9 & BC 7079 & BC 6829 \\
\hline U8 & C009-21 & 8,030 & 35 & -30.1 & BC 7069 & BC 6825 \\
\hline CW1-a & C009-23 & 205 & 30 & -25.1 & AD 1646 & AD 1955 \\
\hline CW1-a & C009-24 & 170 & 30 & -26.0 & AD 1659 & AD 1954 \\
\hline U9 & C009-28 & 8785 & 35 & -25.9 & BC 8167 & BC 7683 \\
\hline CW1-b & C009-33 & 130 & 30 & -14.6 & AD 1675 & AD 1942 \\
\hline CW1-b & C009-36 & 0.0032 & 0.0004 & -24.1 & Modern & $1954 A D^{*}$ \\
\hline U2 & C009-37 & 195 & 30 & -26.1 & AD 1648 & AD 1955 \\
\hline U2 & C009-39 & 130 & 30 & -24.3 & AD 1675 & AD 1942 \\
\hline CW1-a & C009-41 & 180 & 30 & -12.8 & AD 1652 & AD 1955 \\
\hline U2 & C009-42 & 145 & 30 & -25.8 & AD 1668 & AD 1948 \\
\hline $\mathrm{U} 2$ & C009-43 & 130 & 30 & -27.7 & AD 1675 & AD 1942 \\
\hline CW2 & C009-45 & 5,050 & 30 & -26.2 & BC 3952 & BC 3777 \\
\hline U2 & C009-46 & 200 & 30 & -26.3 & AD 1646 & AD 1955 \\
\hline $\mathrm{U} 2$ & C009-48 & 140 & 30 & -26.4 & AD 1669 & AD 1945 \\
\hline $\mathrm{U} 2$ & C009-54 & 140 & 30 & -27.3 & AD 1669 & AD 1945 \\
\hline $\mathrm{U} 2$ & C009-59 & 100 & 30 & -26.2 & AD 1682 & AD 1935 \\
\hline $\mathrm{U} 2$ & C009-67 & 175 & 30 & -11.8 & AD 1656 & AD 1954 \\
\hline U3 & C009-72 & 335 & 30 & -28.1 & AD 1474 & AD 1641 \\
\hline $\mathrm{U} 2$ & C009-76 & 125 & 30 & -10.8 & AD 1677 & AD 1940 \\
\hline $\mathrm{U} 2$ & C009-82 & 110 & 30 & -25.7 & AD 1681 & AD 1938 \\
\hline $\mathrm{U} 2$ & C009-83 & 0.0011 & 0.0001 & -26.4 & Modern & $1954 A D^{*}$ \\
\hline CW1-b & C009-86 & 165 & 30 & -24.0 & AD 1662 & AD 1954 \\
\hline CW1-b & C009-88 & 200 & 40 & -24.6 & AD 1641 & AD 1955 \\
\hline CW1-b & C009-90 & 125 & 30 & -25.5 & AD 1677 & AD 1940 \\
\hline CW1-b & C009-93 & 375 & 30 & -10.9 & AD 1446 & AD 1633 \\
\hline CW1-b & C009-96 & 225 & 30 & -12.1 & AD 1640 & AD 1955 \\
\hline $\mathrm{U} 2$ & C009-99 & 150 & 30 & -25.4 & AD 1667 & AD 1951 \\
\hline CW1-a & C009-103 & 225 & 30 & -25.5 & $\mathrm{AD} 1640$ & AD 1955 \\
\hline $\mathrm{U} 2$ & C009-104 & 185 & 30 & $(-25.0)$ & AD 1650 & AD 1955 \\
\hline CW1-a & C009-106 & 230 & 30 & -25.9 & $\mathrm{AD} 1530$ & AD 1955 \\
\hline $\mathrm{U} 2$ & C009-108 & 225 & 30 & -28.1 & AD 1640 & AD 1955 \\
\hline CW1-a & C009-109 & 230 & 30 & -25.7 & AD 1530 & AD 1955 \\
\hline $\mathrm{U} 4$ & C009-110 & 1,435 & 30 & -25.8 & AD 571 & $\mathrm{AD} 656$ \\
\hline $\mathrm{U} 2$ & C009-116 & 135 & 30 & -28.6 & AD 1671 & AD 1943 \\
\hline $\mathrm{U} 2$ & C009-117 & 185 & 30 & $(-25.0)$ & $\mathrm{AD} 1650$ & AD 1955 \\
\hline $\mathrm{U} 2$ & C009-124 & 280 & 30 & -11.8 & AD 1499 & AD 1796 \\
\hline U2 & C009-126 & 270 & 25 & -25.1 & AD 1521 & AD 1797 \\
\hline $\mathrm{U} 2$ & C009-127 & 160 & 30 & $(-25.0)$ & AD 1664 & AD 1953 \\
\hline $\mathrm{U} 2$ & C009-128 & 240 & 30 & -13.4 & $\mathrm{AD} 1526$ & AD 1955 \\
\hline $\mathrm{U} 2$ & C009-130 & 65 & 30 & -25.2 & AD 1691 & AD 1921 \\
\hline U2 & C009-135 & 125 & 30 & -28.0 & $\mathrm{AD} 1677$ & AD 1940 \\
\hline $\mathrm{U} 2$ & C009-142 & 1.45 & 0.0052 & -25.5 & Modern & 1963 or $1974 A D^{\mathrm{e}}$ \\
\hline CW2 & C009-151 & 5,145 & 30 & -26.6 & BC 4039 & BC 3810 \\
\hline CW2 & C009-152 & 5,115 & 35 & -25.9 & BC 3980 & BC 3800 \\
\hline U2 & C009-153 & 270 & 30 & $(-25.0)$ & AD 1515 & AD 1952 \\
\hline CW2 & C009-155 & 5,080 & 30 & -26.8 & BC 3961 & BC 3797 \\
\hline CW2 & C009-156 & 5,390 & 30 & -25.7 & BC 4336 & BC 4076 \\
\hline $\mathrm{U} 2$ & C009-159 & 1.0584 & 0.0038 & -26.2 & Modern & $1957 A D^{\mathrm{e}}$ \\
\hline CW1-b & C009-166 & 175 & 35 & -25.3 & AD 1652 & AD 1954 \\
\hline CW1-b & C009-167 & 190 & 35 & -19.4 & AD 1646 & AD 1955 \\
\hline CW1-b & C009-178 & 100 & 35 & -24.9 & $\mathrm{AD} 1681$ & AD 1938 \\
\hline CW1-b & C009-179 & 185 & 35 & -26.2 & AD 1648 & AD 1955 \\
\hline $\mathrm{U} 1$ & C009-185 & 1.2985 & 0.0055 & $(-25.0)$ & Modern & 1962 or $1980 A D^{\mathrm{e}}$ \\
\hline $\mathrm{U} 2$ & C009-188 & 140 & 35 & -10.6 & AD 1669 & AD 1945 \\
\hline CW1-b & C009-208 & 380 & 35 & $(-25.0)$ & AD 1442 & $\mathrm{AD} 1634$ \\
\hline
\end{tabular}


Table 2 (continued)

\begin{tabular}{|c|c|c|c|c|c|c|}
\hline \multirow[b]{2}{*}{ Unit $^{\mathrm{a}}$} & \multirow{2}{*}{$\begin{array}{l}\text { Sample } \\
\text { number }\end{array}$} & \multirow{2}{*}{$\begin{array}{c}\text { Measured radiocarbon } \\
\text { age (years BP) }\end{array}$} & \multirow{2}{*}{$\begin{array}{c}\text { Uncertainties radiocarbon } \\
\text { age (years BP) }\end{array}$} & \multirow{2}{*}{$\begin{array}{l}\delta^{13} \mathrm{C} \\
\text { value }^{\mathrm{c}}\end{array}$} & \multicolumn{2}{|c|}{ Calibrated ages (calendric, $2 \sigma)^{\mathrm{d}}$} \\
\hline & & & & & From & To \\
\hline CW1-a & C009-211 & 105 & 35 & $(-25.0)$ & $\mathrm{AD} 1680$ & AD 1939 \\
\hline S1 & $\mathrm{C} 009-223$ & $>45,000$ & - & -23.5 & - & - \\
\hline S1 & $\mathrm{C} 009-225$ & $>45,000$ & - & -28.2 & - & - \\
\hline $\mathrm{U} 4$ & C009-231 & 245 & 35 & -25.5 & AD 1521 & AD 1955 \\
\hline $\mathrm{U} 3$ & C009-237 & 140 & 35 & -27.0 & AD 1669 & AD 1945 \\
\hline U3 & C009-238 & 150 & 35 & -25.3 & AD 1666 & AD 1952 \\
\hline U3 & C009-239 & 235 & 35 & -26.5 & AD 1524 & AD 1955 \\
\hline S1 & C009-223b & $>45,000$ & - & -25.1 & - & - \\
\hline S2 & C009-230a & $>45,000$ & - & -23.5 & - & - \\
\hline $\mathrm{S} 2$ & $\mathrm{C} 009-230 \mathrm{~b}$ & $>45,000$ & - & -26.4 & - & - \\
\hline \multicolumn{7}{|l|}{ Tintale } \\
\hline & TC09-07 & & & & & \\
\hline & & 125 & 30 & -28.5 & AD 1677 & AD 1940 \\
\hline & TC09-08 & & & & & \\
\hline & TC09-I03 & 215 & 30 & -25.0 & AD 1644 & AD 1955 \\
\hline & TC09-I03 & 1.3925 & 0.0050 & -27.3 & Modern & $1963 A D^{\mathrm{e}}$ \\
\hline
\end{tabular}

Note. Samples have been dated by Accelerator Mass Spectrometry measured at the Scottish Universities Environmental Research Center AMS facility. The italicized items correspond to the postbomb ages calcualted with Hua and Barbetti (a different calibration curve than the others).

${ }^{\mathrm{a}}$ See trench logs for stratigraphic unit designations. ${ }^{\mathrm{b}}$ Conventional radiocarbon years BP relative to $1950 \mathrm{AD}$ (with $1 \sigma$ confidence level including counting statistics, as well as reference standard, blank, and random machine errors). ${ }^{c}$ Brackets denote samples for which values are unavailable and assumed to be -25.0. ${ }^{\mathrm{d}}$ Calendar dates were calibrated using the atmospheric calibration curve IntCal13 for the Northern Hemisphere. ${ }^{\mathrm{e}}$ Calendar dates were calibrated using the BOMB04 NH1 calibration curve.

erosional surface shows a low-angle $U$ shape, while this contact is steeper on the eastern wall. The erosional surface truncating all preceding units suggests that a river flowed along the foot of the scarp before deposition of CW1-a. Unit CW1-a is more than 3-m thick in total, thinning southward. It is composed of white-colored Siwalik clasts-more abundant at the top-and rounded pebbles/cobbles and oxidized granules, all embedded in a yellow silty matrix. This colluvial deposit contains pebbles and gravels derived from Units $\mathrm{u} 9$ and $\mathrm{u}$ 7, located higher on the escarpment and that were later reworked during the erosion of a free-face scarp. A smaller similar unit, CW1-b, partly rests on top of CW1-a, while Unit u2 is interbedded with the distal part of CW1-a and CW1-b. Unit u2 consists of 4-m thick alluvial laminated loose fine sands intercalated with clays at its base, turning into white laminated clays at its top. A thin coarse layer, u1, including a small channel, caps the stratigraphic section.

\subsection{Colluvial Wedges, Faulting, Surface Rupture, and Their Relationships to Stratigraphic Units}

On both trench walls, the topmost SW1 unit clearly overthrusts SW2 and Units u7, u8, and u9 along the main thrust-fault $F 1$ (Figures 7 and 8). The shear zone $F 1$ is well defined on both walls, being continuous from the bottom of the trench to the surface, and is only sealed by Unit u1. Its upper termination coincides with the 1-m high scarplet identified at the foot of the cumulative scarp within the topographic data (see Figures $4 \mathrm{e}$ and 6). Fault $F 1$ dips $35^{\circ} \mathrm{N}$ to $50^{\circ} \mathrm{N}$. It includes a dark centimeter to decimeter thick gouge zone (see Figures 8a and 8c). Some pebbles of $\mathrm{u} 9$ are aligned and dragged along Fault F1. Several stacks of alluviums derived from Units $\mathrm{u} 7$ and $\mathrm{u} 8$, which are truncated, are also dragged upward and thrust over each other by secondary fault branches that splay from F1 and end below the coarse sand deposits of Unit u1. This indicates that at least one surface-rupturing earthquake occurred after the deposition of Unit $\mathrm{u} 7$ and prior to the deposition of Unit u1. Moreover, a large slip on F1 may have produced a free-face scarp that could explain the source of material for the massive unsorted wedge-shaped deposits CW2, CW1-a, and CW1-b, which are interpreted as a series of colluvial wedges (McCalpin, 2009).

South of F1, the blocks of SW2 siltstone are deformed and sheared by three fault zones labelled F2, F3, and F4. Fault F2 is truncated within its upper part and sealed by Unit u9, indicating that no surface rupture occurred along this fault strand since the deposition of the gravel bed. Along the shear zone F3, on the west wall, the beds forming SW2 overthrust the upper part of colluvial wedge CW-2, with a minimum measured 

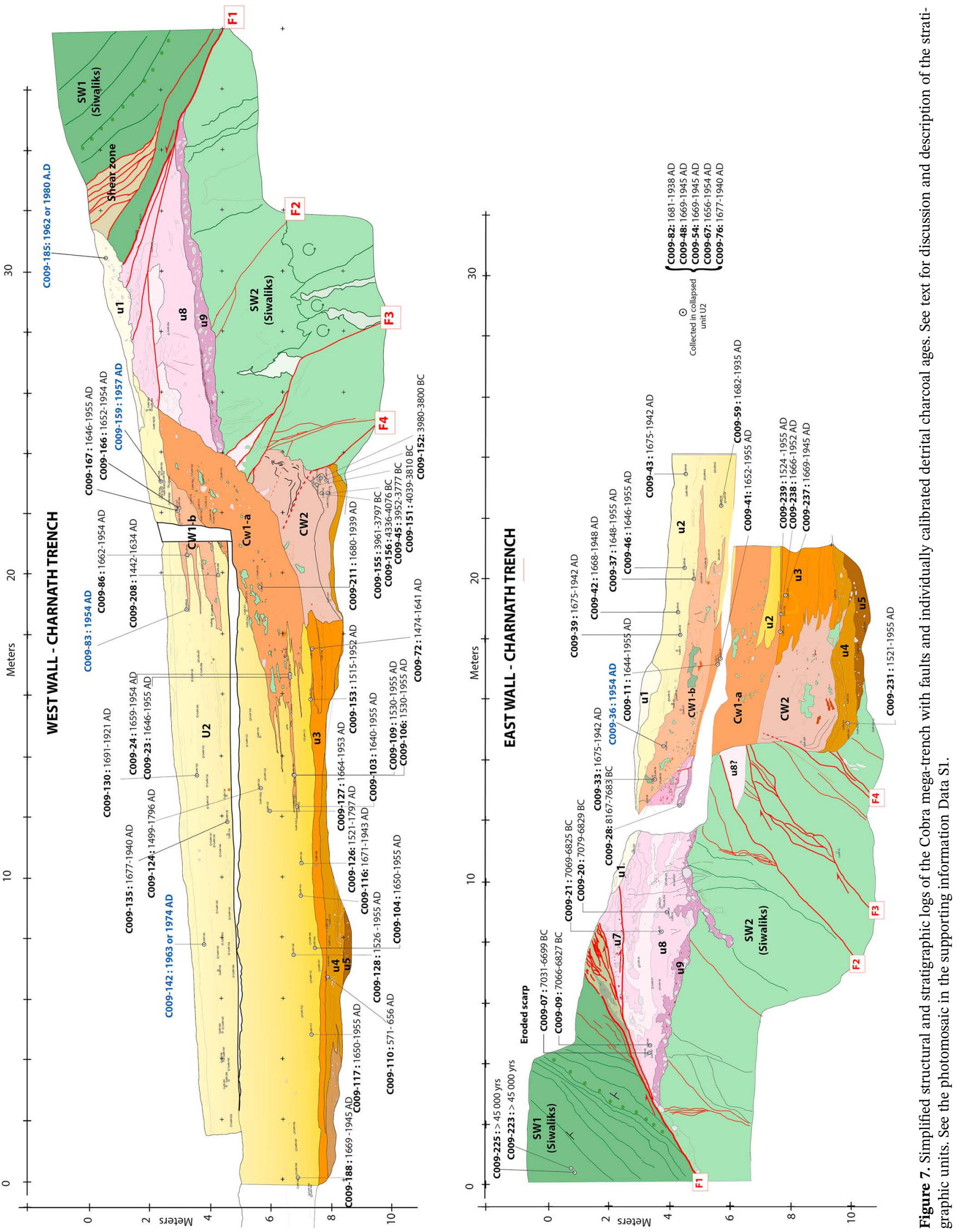
a)

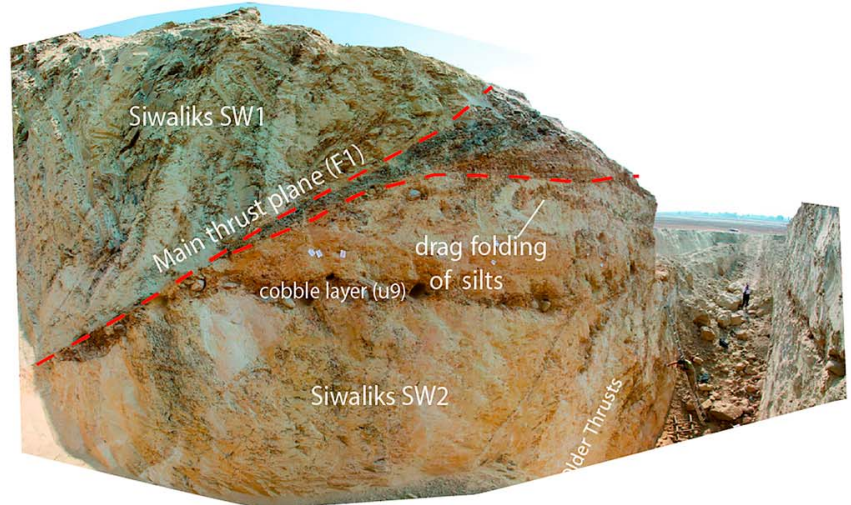

b)
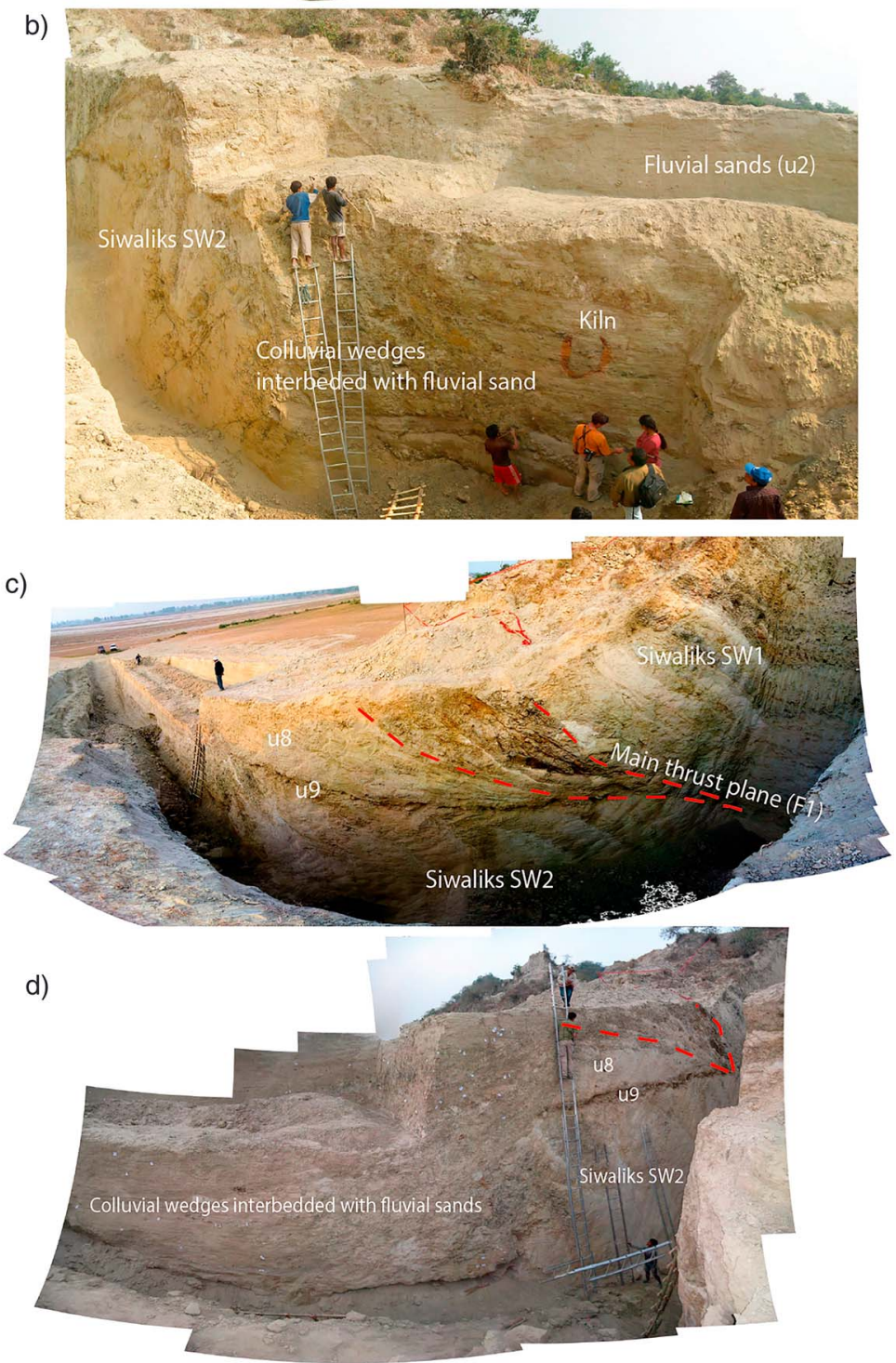

Figure 8. Panoramic field views of the Charnath trench with preliminary interpretations (white text). People are standing in front of the trench for scale purposes. (a) Northern section of the eastern wall with preliminary interpretations (white text) and the main thrust fault labelled F1 in Figure 7 (red dashed line). This view was taken after the collapse of the southern section of the wall. People are standing in front of the wall for scale purposes. (b) Field view of the eastern wall taken after the collapse of the southern section of the wall. Preliminary interpretations (white text) are reported. The kiln can be clearly seen with the orange color on the sediments. People are standing in front of the wall for scale purposes. (c) Panoramic view of the northern section of the western wall with preliminary interpretations (white text) and the main thrust fault labelled F1 in Figure 7 (red dashed line). (d) Panoramic view of the southern section of the western wall with preliminary interpretations (white text) and the main thrust fault labelled F1 in Figure 7 (red dashed line). 


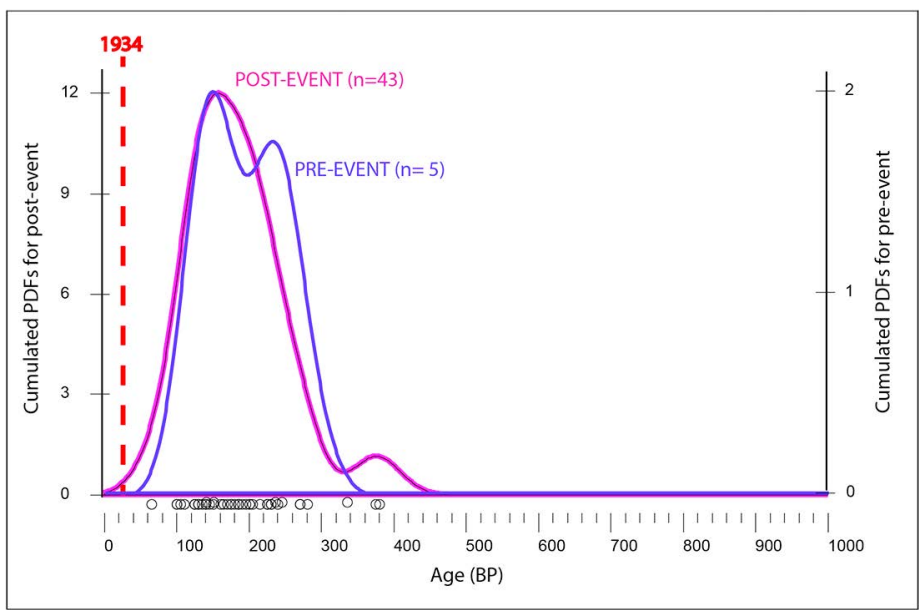

Figure 9. Probability density plots for ${ }^{14} \mathrm{C}$ sample predating (blue) and postdating (purple) the event horizon at the Charnath trench using the DensityPlotter program (Vermeesch, 2012). The open black dots on the bottom scale represent the individual ages. The ${ }^{14} \mathrm{C}$ ages present similar radiocarbon ages, so we cannot establish whether sediments are deposited during distinct phases. offset of $1.2 \mathrm{~m}$. At its upper termination, F3 is truncated and sealed by the CW1-a colluvial wedge. On the east wall, F3 is truncated by a sharp erosional contact and covered by the thick body of colluvial wedge CW1-a.

On the two trench walls, the bases of both Units CW-2 and $\mathrm{u} 4$ are offset, with small-scale drag folding along the F4 fault zone. Along F4, Siwalik SW2 blocks overthrust colluvial wedge CW2, with a minimum offset measured at $0.8 \mathrm{~m}$, along sharp vertical fault planes. These fault planes become less clear at the base of CW2, but we were able to follow their upper continuation up to the unfaulted base of CW1-a. We interpret that the base of CW1-a caps the tip of the fault splays F3 and F4, pointing to a surface-rupturing earthquake that must postdate CW2 and predate CW1-a. Moreover, on the eastern wall, colluvial wedge CW1-a overlies u3 and, therefore, must postdate the kiln activity (marking a ground level). The shallowest units (u2, CW1a, 1b, and $\mathrm{u} 1$ ) are not faulted.

Therefore, our observations suggest that no fault located below F1 in the section has reached the surface since the beginning of the deposition of colluvial wedge CW1-a and Unit $\mathrm{u} 2$.

\subsection{Radiocarbon Dating of the Detrital Charcoal Samples of the Stratigraphic Sequence in the Cobra Trench}

We dated 69 samples out of 230 charcoal fragments collected. The charcoal samples were prepared and dated at the Scottish Universities Environmental Research Centre AMS facility (Table 2). We first individually calibrated each sample using the radiocarbon calibration program Oxcal V4.2.4. We used the calibration curve IntCal13 (Reimer et al., 2013). Our detrital charcoal age distribution falls mainly within a period for which the calibration curve is almost flat (65-225 BP, late seventeenth to early twentieth century). Hence, the probability distribution for each calibrated age is large, often exceeding 200 years (Table 2). Post-1950 samples are considered as modern and need to be calibrated using a different calibration procedure. We therefore complemented the individual calibrations using the calibration curve Bomb04NH1 (Hua \& Barbetti, 2004) adapted to the "modern" samples (i.e., post-0 BP or $1950 \mathrm{CE}$ ).

The radiocarbon dating of the detrital charcoals collected in Units u9 (CO09-28) and u8 (CO09-07, 09, 20, and 21) yield ${ }^{14} \mathrm{C}$ calibrated ages ranging between 7079 and $6825 \mathrm{BC}$. In the footwall of the trench, combining the trench observation and ages shows that deposition of colluvial wedge CW2 happened after the deposition of u4 and was coeval to the deposition of Unit u3. The detrital charcoal samples CO09-110 and CO09-231, collected in a stratigraphic position below CW2, yield ${ }^{14} \mathrm{C}$ calibrated ages of 571-656 AD and 1521-1955 AD, respectively. These samples post-date by $\sim 4,500$ to $\sim 6,000$ years the five detrital charcoal pieces (CO09-45, 151, 152, 155, and 156) within $\mathrm{CW} 2$, with ${ }^{14} \mathrm{C}$ calibrated ages ranging between 4340 and $3810 \mathrm{BC}$ (see Figure 7). Four detrital charcoal samples (CO09-72, 237, 238, and 239), collected in Unit u3, interbedded with CW2, return ages between 1474 and 1955 AD. This suggests that the detrital charcoal samples collected within CW2 are all reworked.

The 43 charcoal samples collected from Units u2, CW1-a, and CW1-b yield comparable calibrated ages to those found in $\mathrm{u} 3$ and $\mathrm{u} 4$, with ages ranging from 1650 to $1955 \mathrm{AD}$. These ages fall in the same time span as those collected from Unit u3 (see Figure 9). However, some of the detrital charcoals sampled in CW1-b (C009-36), at the top of Unit u2 (CO09-83, 142, 159, and 185) and in Unit u1 (CO09-185), yield modern ages, indicating that these units were deposited between 1954 and 1980 AD. Deposits at the toe of the scarp are related to colluvial wedges interbedded with fluvial sequences, and we suspect that some detrital charcoals may have been washed by the river or may have collapsed from the scarp down to colluvial wedge CW2. This scenario would explain the rather old ages of detrital charcoals incorporated within Units CW1-a, CW1-b, and u2.

\subsection{Earthquake Series}

In the trench, we defined one surface-rupturing earthquake horizon and three colluvial wedges in the footwall of the main fault F1. The origin of the colluvial wedges could be related either to individual earthquake 


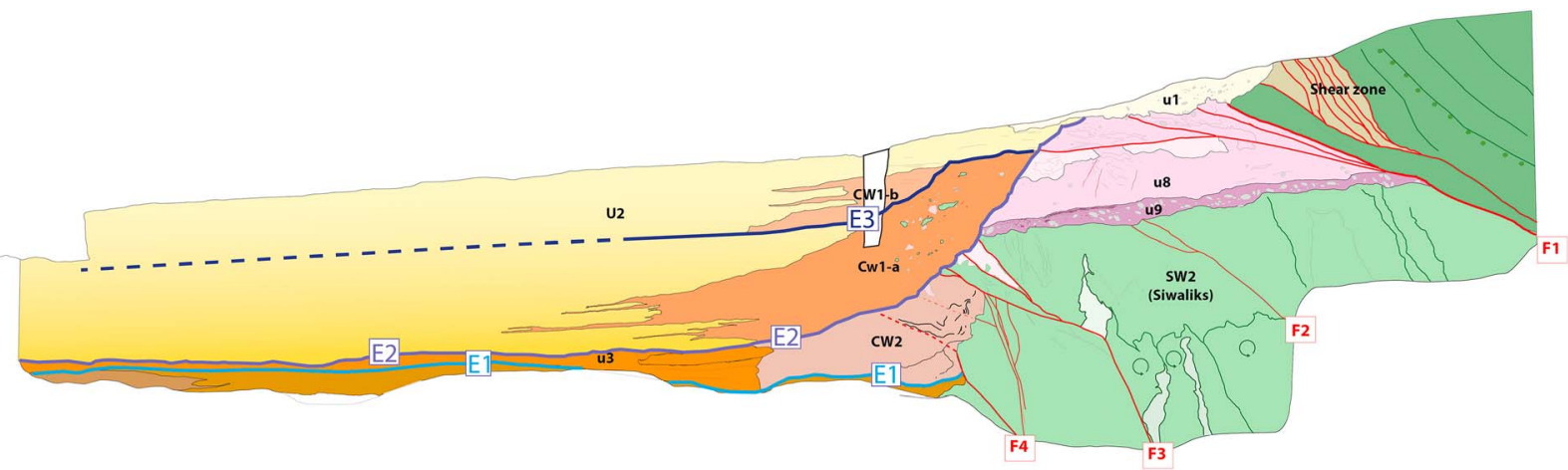

Figure 10. Simplified paleoseismic log of the western wall of the Cobra trench. Earthquake horizons defined from our stratigraphic observations are highlighted by the blue lines and labelled E1, E2, and E3. See text for details.

ruptures, weathering, or strong seismic shaking not necessarily related to a surface rupture at the Charnath Khola. Each time that the sediments reached a level of peak ground acceleration, the local soil structure would be weakened and prone to remobilization by erosion to form colluvial wedges at the ground surface. We now refine our stratigraphic observations of earthquake series by combining trench observation with available chronological data to constrain the timing of the earthquake horizons.

An earthquake horizon E1 (Figure 10) is defined at the base of colluvial wedge CW2. The radiocarbon ages and stratigraphy indicate that the lower colluvial wedge, CW2, was necessarily deposited after $1521 \mathrm{AD}$ (CO09-231). Three samples (CO09-237, 238, and 239) collected near the kiln, at the top of u3, postdate the deposition of colluvial wedge CW2 at $1524 \mathrm{AD}$ (minimum age for CO09-239). A second event horizon E2 (Figure 10) postdates the deposition of $\mathrm{u} 3$ and $\mathrm{CW} 2$, as they are affected by significant offsets and dragfolding along the F3 and F4 faults.

The undisturbed 4-m thick fluvial sediments at the frontal fault scarp postdate the earthquake horizon E2. Colluvial wedge CW1-a seals the rupture and likely corresponds to a massive influx of sediments emplaced right after this surface rupture. Hence, the earthquake horizon E2 is located between the top of u3/CW2 (i.e., 1524 AD) and the base of colluvial wedge CW1-a. Detrital charcoal samples collected in Units CW1-a and in the lowest part of Unit u2 return radiocarbon ages similar to those collected in Unit u3. None of the 12 charcoal fragments sampled within CW1-a and in the lowermost part of Unit u2, which is interfingered with CW1-a, are modern. Hence, this suggests a prebomb deposition of CW1-a and u2. The second colluvial wedge, CW1-b, interfingered with sands from the upper part of Unit u2, lies on top of CW1-a. We posit an earthquake horizon E3 (Figure 10) at the base of CW1-b. Among a large number of collected detrital charcoals, five samples collected in CW1-b (C009-36), at the top of Unit u2 (CO09-83, 142, 159, and 185) and within Unit u1 (CO09-185) yield modern ages, indicating that these units were deposited after 1954 AD (calibrated ages for CO09-36 and 83).

Among the three event horizons identified in our trench, event horizon E2 corresponds to the most recent actual surface rupture identified in the trench. It also corresponds to the largest deformations that can be directly identified in the trench.

\section{Abandoned Terraces of the Charnath Khola as a Record of Large Earthquakes}

\subsection{Methodology for the Morphotectonic Survey of the Western Riverbank}

We extensively surveyed the banks of the Charnath Khola where several large, flat, alluvial surfaces were abandoned. We mapped and labelled the terraces upward from the lowest base level (T0) to the uppermost surface (T6; Figures 2 and 3). The spatial relationship between the various MFT fault strands and the system of abandoned fluvial terraces in the hanging wall was documented using aerial photographs acquired in 1964 and recent HR Ikonos satellite images (2010). These images are complemented with topography derived from a Total Station survey (TS, resolution of $2 \mathrm{~m}$ ) and from an airborne Lidar survey (resolution of $1 \mathrm{~m}$ ) conducted, respectively, in 2009 and 2015 (see supporting information Data S3 for more details). The fluvial terrace elevation above the present Charnath, Saphi, and Kariya riverbeds, as well as upstream 

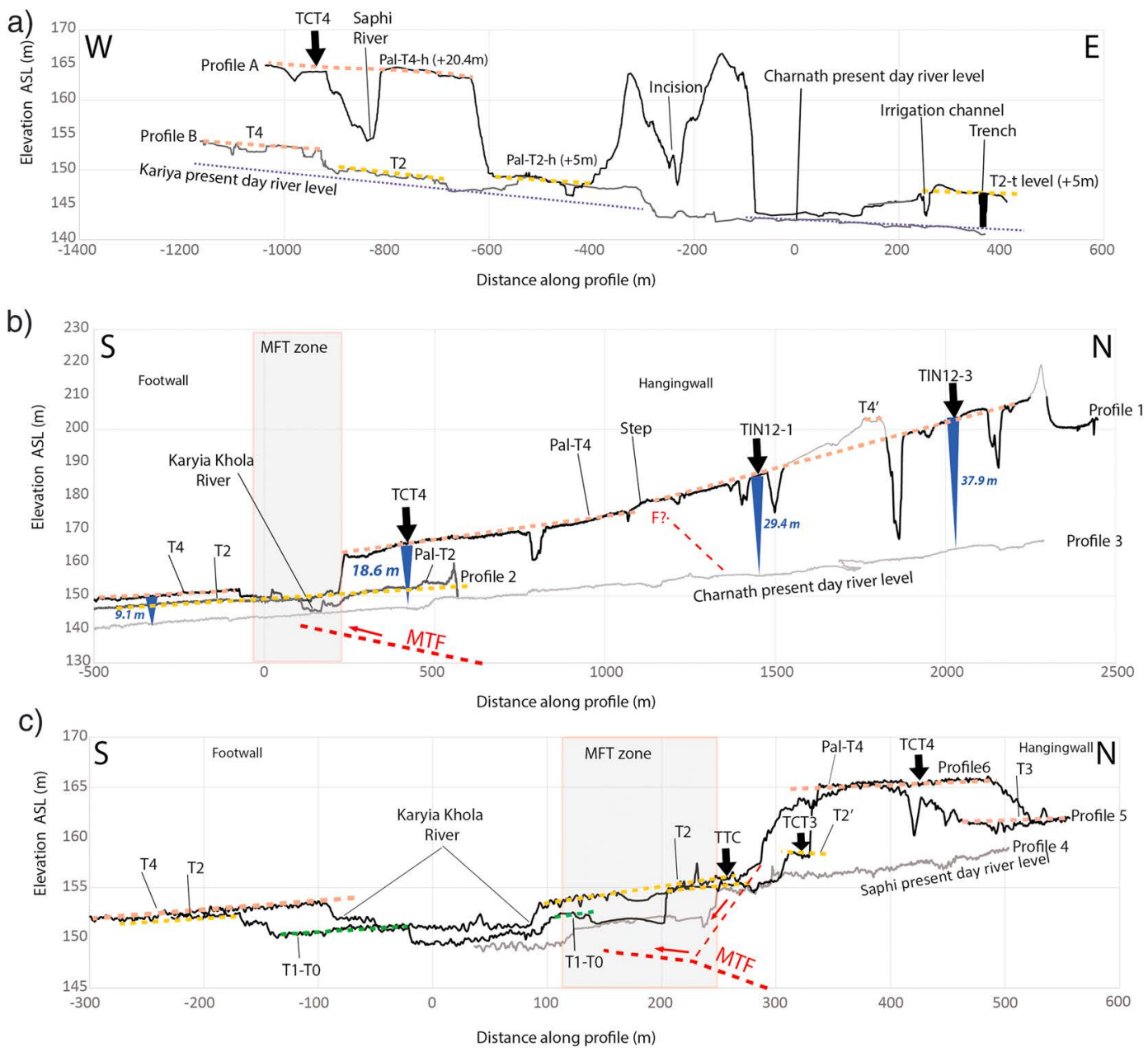

Figure 11. Topographic profiles across the Charnath Khola fluvial terraces (see location in Figure 2) with morphological interpretations (colors are similar to Figure 3). (a) Topographic profiles PA and PB with a vertical exaggeration projected along a west-east axis. (b) Topographic profiles P1, P2, and P3 with a vertical exaggeration projected along a north-south axis. Arrows indicate the pit positions; blue arrows indicate the estimated incision from the terrace level to the present-day level base of the Charnath Khola. The dashed line with the label (F?) represents an inferred active thrust fault in the MFT's hanging wall. The expected position of the MFT is represented by the grey box. (c) Topographic Profiles P4, P5, and P6 with a vertical exaggeration projected along a north-south axis around the Tintale Creek site (see location in Figure 2). Arrows indicate the pit positions and the expected position of the MFT is represented by the grey box.

and downstream correlations, were derived from topographic profiles parallel to the MFT and along the rivers and paleo-river courses (Figure 11).

\subsection{Principal Geomorphic Observations}

Along a thrust fault, after a major earthquake, the base level of the river is mainly affected by a coseismic uplift in the hanging wall that triggers regressive erosion (Graveleau et al., 2015) and by local subsidence in the footwall that partly controls the aggradation of sediments made available by numerous landslides upstream (Korup, 2005; Korup et al., 2004). In the hanging wall of the MFT, west of the present-day river course, we mapped two paleo-meanders, Pal-T2 and Pal-T4, respectively, at +5-m and +19-m above the current riverbed (Figures 3 and 11). They are remnants of the ancient course of the Charnath Khola. Two western tributaries of the Charnath Khola, the Saphi, and Kariya Khola add some complexity to the landscape: the Kariya Khola flows parallel to the MFT and likely erodes part of the frontal seismic scarp, as observed at Tintale Creek; the Saphi Khola flows across the MFT zone and formed a system of inset fill-cut terraces, nearly perpendicularly to the seismic scarp, since the abandonment of the terrace Pal-T4 tread by the 
Charnath Khola. The three rivers adjust to local and regional changes induced by tectonic events through the mobilization of sediments.

The two topographic profiles PA and PB (Figure 2) are parallel to the MFT. They highlight the presence of two distinct terrace treads associated with T2 and T4 (Figure 11a). Profile PA reveals that Pal-T2, located in the hanging wall, stands 4- to 5-m above the present base level of the Charnath Khola, at the same elevation as the T2-t level, which is located in the footwall (Figure 11a-profile PA). Thus, Topographic Profile P2 (Figures 11b and 11c) shows that the alluvial surface T2 presents no net vertical offset across the MFT fault zone. Hence, this surface was still to be active after the most recent surface-rupturing earthquake. We suggest that the absence of a noticeable offset through the meander could be due to a post-earthquake aggradation. This aggradation would relate to a regional enhanced mass-wasting episode. It is also consistent with the fact that in the trench the most recent fault scarp is buried below 4-5 $\mathrm{m}$ of recent fluvial deposits. Together, all of these observations imply that the aggradation and subsequent abandonment of Paleomeander Pal-T2 with the incision of the Charnath Khola into its present-day level followed the most recent large earthquake at the Charnath site.

In the footwall of the MFT, the T4 terrace stands 9-m above the present riverbed of the Charnath Khola. In the hanging wall, its elevation above the present-day riverbed increases northward from $\sim 19$ to $\sim 38 \mathrm{~m}$ within the first $2 \mathrm{~km}$ from the MFT (Figure 11b). The topographic profiles along the tread reveal its vertical offset in the vicinity of the frontal thrust (MTF on Profile 1 Figure 11b). They also reveal an abrupt steepening of the tread, from 2.5 to $5.1{ }^{\circ} \mathrm{S}$, above what we interpret as a secondary blind reverse fault connected to the MFT at depth (see the dashed red fault $\mathrm{F}^{\prime}$ in Figure 11b). We attribute part of the tilting and northward increase in incision to the growth of an anticline. This scenario is consistent with the dips and strike directions measured in Siwalik beds (reported in Figure 3) and with what can be seen on a seismic line shot along the Charnath Khola (see supporting information Data S4).

At the confluence between the Kariya and Saphi Khola, Pal-T4 treads present an apparent vertical offset of $\sim 14 \mathrm{~m}$ across the MFT zone (Figure 11c). A cultivated flat surface T2 (Figure 3), already observed in 1964 aerial photos, stands $\sim 4-\mathrm{m}$ above the Kariya stream bed (Figure 11c). The same level T2 is also mapped upstream, standing $\sim 2.5-\mathrm{m}$ above the riverbed (Figure 11c). Similarly, to what was found earlier for Pal$\mathrm{T} 2$, this alluvial surface T2 presents no vertical offset across the MFT fault zone, suggesting that this level was probably still active for some time after the last surface-rupturing earthquake.

\subsection{Radiocarbon Dating of Abandoned Terraces and Correlation With Past Earthquakes}

Although no direct observation of a coseismic uplift was ever reported for the 1934 earthquake, levelling data suggest that at least $1.2 \mathrm{~m}$ of subsidence occurred in the Gangetic foreland, following the 1934 earthquake (Bilham et al., 1998; Bomford, 1937; Bollinger et al., 2014). In addition, numerous large earthquake-triggered landslides were reported affecting the Siwaliks in the region (Rana, 1935). Hence, it is likely that a significant episode of aggradation leading to a delayed abandonment of Pal-T2 and subsequent incision of a new riverbed followed the 1934 earthquake. Four detrital charcoal samples were collected on the T2 level in Pits TCT3 and TTC (see location in Figures 3 and 11c) that yield calibrated ages ranging from 1648 to 1955AD (Table 3), falling in a period similar to the most recent active period documented in the trench. According to the TS09-04 sample (Table 3), the level T2 was abandoned and incised by the Saphi Khola sometime after 1955AD. Thus, we suggest that the earthquake that eventually led to the abandonment of T2 is the 1934 earthquake. Four detrital charcoal samples were collected in fluvial layers forming the Pal-T4 terrace that

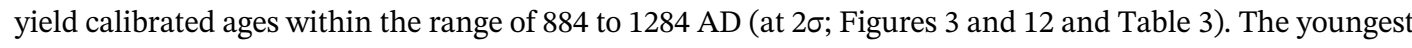
charcoal sample attests of the activity of Pal-T4 until at least the very beginning of the thirteenth century. Four additional detrital charcoals were collected in fine-matrix layers located in the upper part of the pit. These units are characteristic of a low-energy transport environment, and we interpret these units as overbank flood deposits emplaced after the abandonment of Pal-T4. According to the ages of the younger charcoal samples (TS09-05 and 06 at 565 and $535 \pm 30 \mathrm{BP}$ ), these overbank deposits must postdate the early fourteenth century, and thus, the abandonment of Pal-T4 must have happened during the thirteenth or early fourteenth century (Figure 12b). Similarly to Pal-T2, we postulate that the abandonment of Pal-T4 could be related to some large earthquake locally triggering an aggradation episode (depending on the amount of landslide debris available upward in the watershed, as well as on the capacity of the river to mobilize, 
Table 3

AMS Radiocarbon $\left({ }^{14}\right.$ C) Dates From Detrital Charcoals Collected From Terrace Levels at Charnath Khola

\begin{tabular}{|c|c|c|c|c|c|c|c|}
\hline \multirow[b]{2}{*}{ Pit labels ${ }^{\mathrm{a}}$} & \multirow[b]{2}{*}{ Level name } & \multirow{2}{*}{$\begin{array}{l}\text { Sample } \\
\text { number }\end{array}$} & \multirow{2}{*}{$\begin{array}{l}\text { Measured radiocarbon } \\
\text { age (years BP) }\end{array}$} & \multirow{2}{*}{$\begin{array}{c}\text { Uncertainties radiocarbon } \\
\text { age (years B.P) }\end{array}$} & \multirow{2}{*}{$\begin{array}{c}\delta^{13} \mathrm{C} \\
\text { value }\end{array}$} & \multicolumn{2}{|c|}{ Calibrated ages $^{\mathrm{c}}(\mathrm{AD}, 2 \sigma)$} \\
\hline & & & & & & From & To \\
\hline $2 \mathrm{TT}$ & Pal-T4 & TS09-05 & 535 & 30 & -27.5 & 1318 & 1439 \\
\hline $1 \mathrm{TT}$ & Pal-T4 & TS09-06 & 565 & 30 & -26.0 & 1306 & 1426 \\
\hline TCT4 & Pal-T4 & TS09-08 & 1,080 & 30 & $-25.0^{\mathrm{d}}$ & 894 & 1018 \\
\hline BB (footwall) & Pal-T4 (footwall) & BB09-01 & 1,260 & 40 & -27.7 & 668 & 870 \\
\hline TIN12-3 & Pal-T4 & TIN12-Pit3-01 & 838 & 26 & -25.1 & 1160 & 1260 \\
\hline TIN12-3 & Pal-T4 & TIN12-Pit3-03 & 778 & 34 & -27.3 & 1190 & 1284 \\
\hline TIN12-3 & Pal-T4 & TIN12-Pit3-07 & 840 & 34 & -27.5 & 1053 & 1267 \\
\hline TIN12-3 & Pal-T4 & TIN12-Pit3-09 & 934 & 34 & -29.2 & 1022 & 1175 \\
\hline TIN12-1 & Pal-T4 & TIN12-Pit1-01 & 895 & 34 & -25.4 & 1039 & 1215 \\
\hline TCT3 & $\mathrm{T} 2$ & TS09-07 & 150 & 30 & -26.3 & 1667 & 1951 \\
\hline TTC & $\mathrm{T} 2$ & TS09-01 & 75 & 30 & -27.7 & 1691 & 1925 \\
\hline TTC & $\mathrm{T} 2$ & TS09-02 & 105 & 30 & -28.7 & 1681 & 1937 \\
\hline TTC & $\mathrm{T} 2$ & TS09-04 & 195 & 30 & -27.5 & 1648 & 1955 \\
\hline
\end{tabular}

${ }^{\mathrm{a}}$ See Figures 2 and 3 for locations and Figure 12 for stratigraphic logs. ${ }^{\mathrm{b}}$ Conventional radiocarbon years BP relative to $1950 \mathrm{AD}$ (with $1 \sigma$ confidence level including counting statistics, as well as reference standard, blank, and random machine errors). ${ }^{c}$ Calendar dates were calibrated using the atmospheric calibration curve IntCal13 for the Northern Hemisphere. ${ }^{\mathrm{d}}$ Samples for which values are unavailable and assumed to be -25.0.

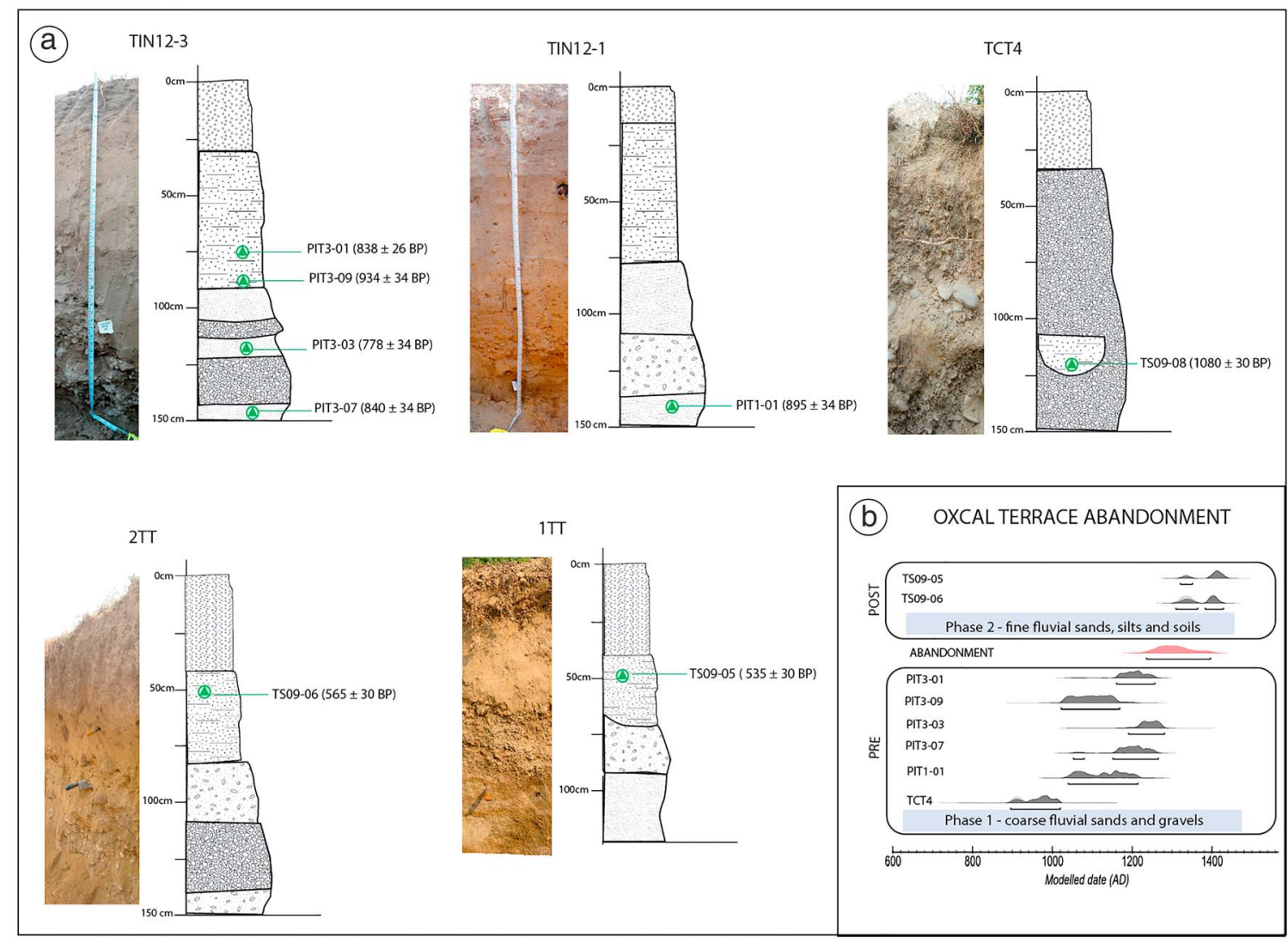

Figure 12. (a) Schematic logs of pits excavated on Terrace Pal-T4 (see Figures 2 and 3 for location). Uncalibrated ages of detrital charcoals (triangles). (b) Calibrated radiocarbon ages and modelled probability age spectra for earthquake E2, associated with Pal-T4 terrace abandonment. Oxcal chronostratigraphic sequence with wo phases: (1) one preabandonment of the alluvial level with gravel and sand deposits and (2) one postabandonment with silts and sands from low-energy deposits and soil development at the top. 
transport, and deposit this debris) and the entrenchment of the river, similarly to what happened after the 1934 AD earthquake.

Using the Oxcal software (Bronk Ramsey, 2008), we ran a simple Bayesian model of this scenario as a sequence of two phases of deposition (i.e., a fluvial period followed by abandonment and the sedimentation of overbank deposits). This model allows a period that falls between 1236 and 1396 AD (Figure 12b) to be determined for the abandonment of Pal-T4. This period includes the devastating earthquakes of 1255 and $1344 \mathrm{AD}$, both well documented in the chronicles (Pant, 2002). Although the $1344 \mathrm{AD}$ earthquake was very destructive (Pant, 2002), its surface rupture is usually located farther west along the MFT (Bollinger et al., 2016; Mugnier et al., 2013). Instead, surface ruptures associated with 1255 have been documented both west of the Charnath site, at $\sim 20 \mathrm{~km}$ at the Sir Khola (Bollinger et al., 2014, 2016; Sapkota et al., 2013), and at $\sim 65$ km at Bagmati (Wesnousky, Kumahara, Chamlagain, Pierce, Reedy, et al., 2017), and 160-km eastward at Damak (Wesnousky, Kumahara, Chamlagain, Pierce, Karki, et al., 2017). Hence, the Charnath site is located within the area of potential surface rupture of the $1255 \mathrm{AD}$ earthquake, and for this reason, we suggest that this earthquake is likely responsible for the abandonment of Pal-T4.

\section{Discussions: Past Events and Their Morphotectonic Implications}

The geomorphologic survey and paleoseismic excavation, constrained by radiocarbon dates, provide a unique insight into the chronological relation between aggradation, incision, and the occurrence of major earthquake ruptures along the Charnath strand of the MFT. We combine hereafter all of the observations and results deduced from chronological dating, historical catalogues, and aerial photographs, in order to constrain the dates of paleo-earthquakes and the sedimentation rates following these events.

\subsection{Earthquake Timing Tested With A Priori Stratigraphical and/or Historical Observations}

The Cobra trench yields information only about one recent surface rupture, although it includes three colluvial wedges, all younger than the fifteenth century. The colluvial wedges could result either (1) from coseismic offsets on Fault F1 associated with the generation of a free-face scarp and its rapid collapse or (2) from delayed incremental collapse of the scarp, either due to weathering episodes or to strong ground motion associated with significant regional earthquakes.

Based on observations made above thrust faults in steep topography environments, the density of earthquake-triggered landslides is high when the horizontal peak ground acceleration exceeds $0.2 \mathrm{~g}$ (Meunier et al., 2007). Such acceleration values are typically reached in regions that were exposed to Modified Mercali intensities (MMIs) greater than VI (e.g., Wald et al., 1999). We therefore test a model in which we define three event horizons, namely E1, E2, and E3 (see the position of the earthquake horizons in Figure 10). These events are, respectively, related to the deposition of colluvial wedge CW2 (E1), to the surface rupture followed by the deposition of colluvial wedge CW1-a (E2) and to the deposition of colluvial wedge CW1-b (E3).

The chronology of the events appears to be loosely constrained by individually calibrated radiocarbon ages (69 dates), since the ${ }^{14} \mathrm{C}$ calibration curve is almost flat between the seventeenth and the twentieth century. We therefore attempt to refine the chronology by adding a priori stratigraphic and/or historical information in a radiocarbon calibration, by using a Bayesian approach (Oxcal, Bronk Ramsey, 2008). Three alternative models (see supporting information Data S2) are tested by combining different phases (groups of charcoal samples with no internally defined stratigraphic relations) or sequences (group of samples in a given stratigraphic order).

\subsubsection{Model M1 With No Reworking Nor Inbuilt Ages for Detrital Charcoals and Negligible}

\section{Transport Times}

In a first model M1, we consider as much as possible that reworking of charcoal samples, inbuilt ages (i.e., age of the wood at the time of burning), and transport time before deposition, are negligible in both the colluvial wedges and alluvials. However, reworking of some of the charcoal samples in the colluvial wedges cannot be neglected: Some of the detrital charcoals sampled in CW2 (i.e., CO09-45/151/152/155/156) predate the radiocarbon ages of the samples found in the fluvial sands located below. Thus, these samples had to be removed from the data set of Model M1. Model M1 considers a sequence of four phases of 

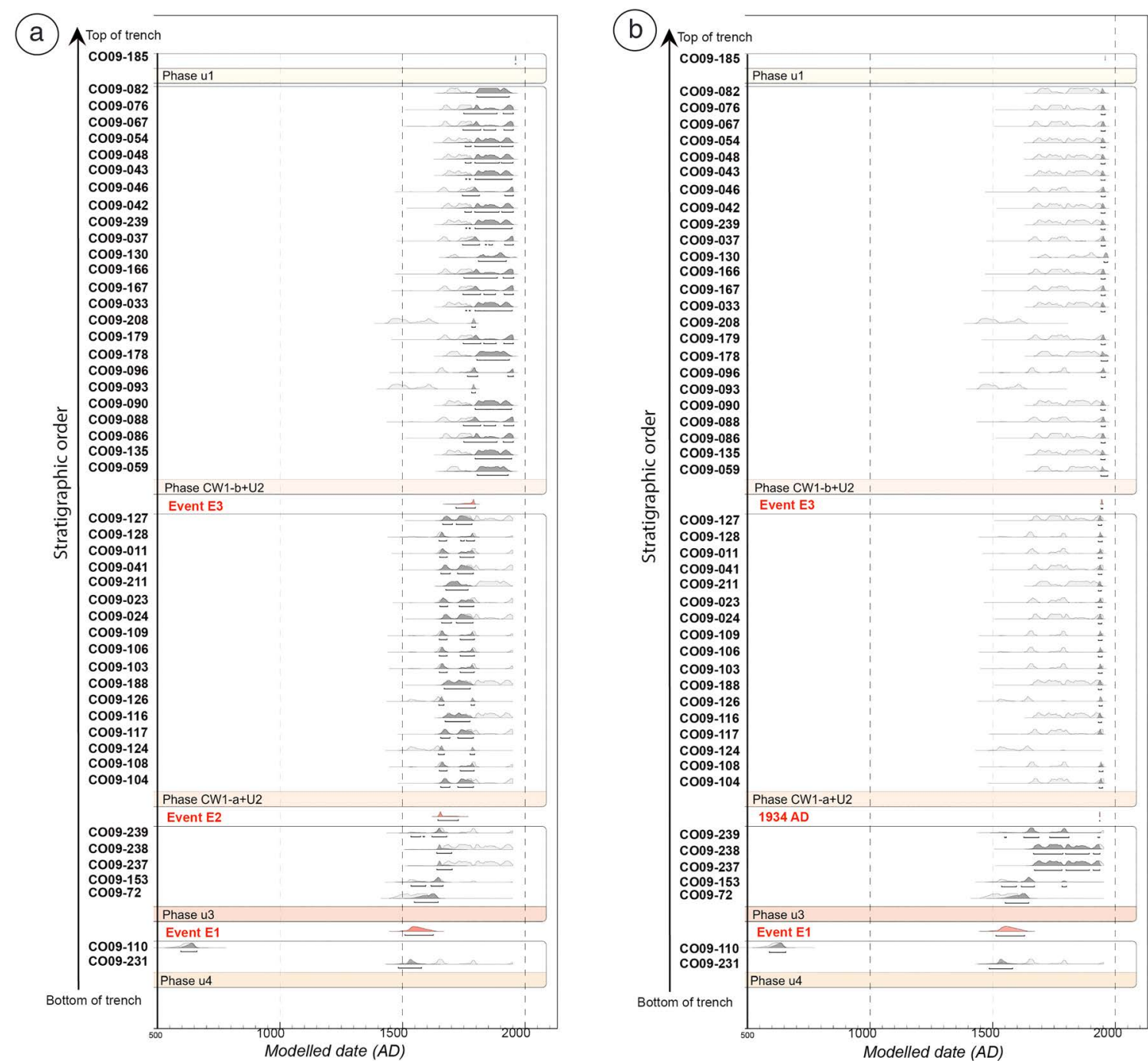

Figure 13. Model M1 built from the stratigraphic information from logged units with three event horizons (E1, E2, and E3) placed from our paleoseismic interpretations (see also Figure 10). In this model we consider that reworking, inbuilt ages for charcoal samples (i.e., age of the wood at the time of burning) and transport time before deposition are negligible. Detrital charcoal radiocarbon ages from both walls using Oxcal 4.2.4 (Ramsey, 2013) chronostratigraphic models with IntCal13 atmospheric calibration curve (Reimer et al., 2013). Light and dark grey probability spectra, respectively, indicate the individually calibrated and modelled ages. Red probability spectra indicate the modelled ages for E1, E2, and E3. (a) Occurrence dates are between 1510 and 1626 AD for E1, 1645 and $1728 \mathrm{AD}$ for E2, and 1721 and $1798 \mathrm{AD}$ for E3. (b) A similar model with an earthquake horizon E2 fixed at $1934 \mathrm{AD}$ and used as a priori input. Given that their individual curve calibrations are different to the whole set of samples, C009-93, 124, and 208 are considered as outliers.

deposition in the trench. The output age model associates E1 with the period 1510-1626 AD, E2 to 1645$1728 \mathrm{AD}$ and E3 with 1721-1798 AD (Figure 13a).

\subsubsection{Model M2, Minimizing the Inbuilt Age, Transport, and Reworking Biases}

The assumptions used to build the first model might bias the solution and make the events seem older than they really are. For example, some charcoal pieces sampled in the colluvial wedge have probably been significantly reworked or incorporate large inbuilt ages (e.g., CO09-093 and 208, which appear significantly older than the average in CW1b), although they are still compatible with Model M1. The distribution of radiocarbon ages from the topmost units (CW1-a, CW1-b, u2, and u1) reveals that they present a mix of prebomb and postbomb dates. The five of the 48 samples collected in these units, calibrated using the Bomb04NH1 curve (Hua \& Barbetti, 2004), return modern ages ranging from 1954 to 1963 AD. These very young ages demonstrate that $\sim 90 \%$ of the detrital charcoals may, in fact, be significantly older than the true age of deposition, due to inbuilt ages, transport, or reworking (e.g., Bollinger et al., 2016; Dezileau et al., 2014; Gavin, 2001). These detrital charcoals may be responsible for an apparent aging of the earthquake 

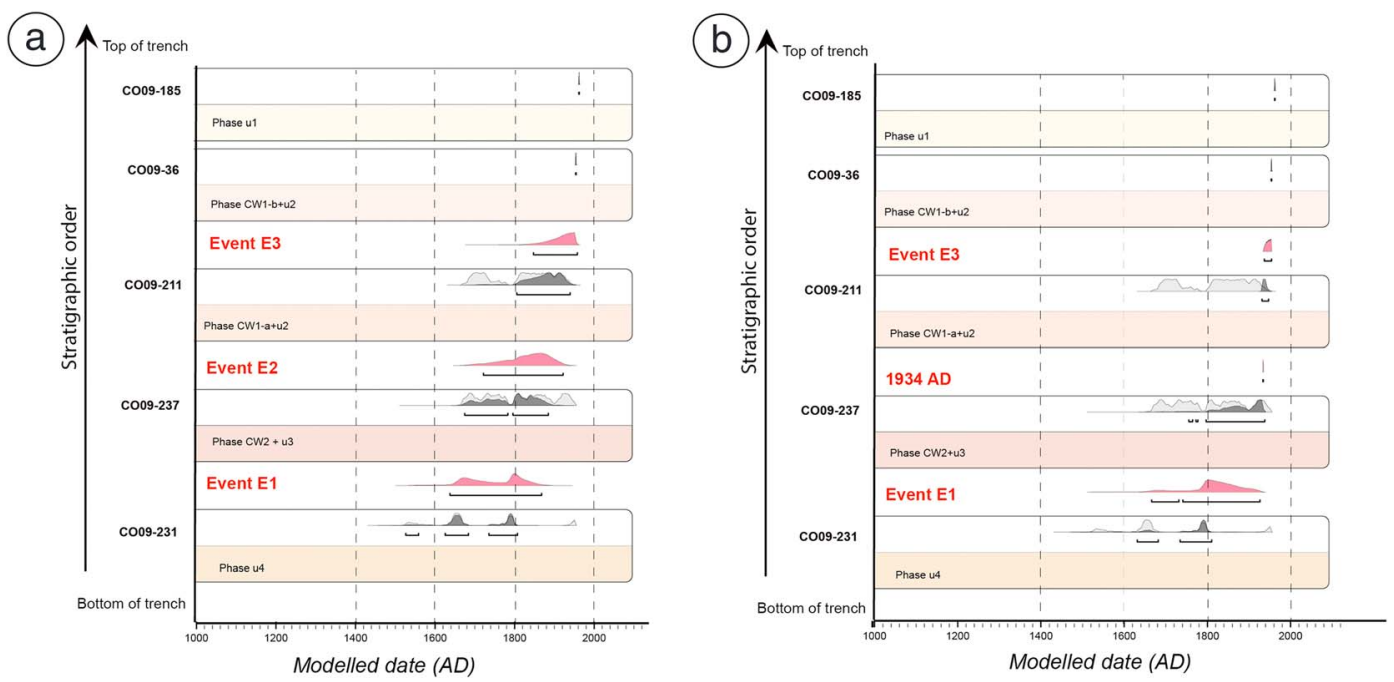

Figure 14. Model M2 built from the stratigraphic information from logged units with three event horizons (E1, E2, and E3) placed from our paleoseismic interpretations (see also Figure 10). In this model, we consider that most detrital charcoals are reworked but that inbuilt ages for charcoal samples (i.e., age of the wood at the time of burning) and transport time before deposition are negligible. We construct a simplified chronostratigraphic model with IntCal13 atmospheric calibration curve (Reimer et al., 2013). Light and dark grey probability spectra, respectively, for individually calibrated and modelled ages. Red probability spectra indicate the modelled ages for E1, E2, and E3. (a) Occurrence dates are between 1636 and $1870 \mathrm{AD}$ for E1, 1720 and $1923 \mathrm{AD}$ for E2, and 1849 and $1958 \mathrm{AD}$ for E3. (b) A similar model with an earthquake horizon E2 fixed at $1934 \mathrm{AD}$ and used as a priori input.

horizon timing, a scenario already documented in other settings (Atwater et al., 1990). Adding data points in a model taking every charcoal sample available does not necessarily reduce the bias arising from the prior assumptions related to inbuilt age and transport time lags. However, selecting the youngest detrital charcoal in every unit necessarily reduces this bias. The more charcoal sample available, the higher the probability of dating a charcoal sample with very small inbuilt age and transport time lags.

Therefore, we assume hereafter that the youngest detrital charcoal sampled in every unit is that incorporating the least inbuilt age, transport and reworking. We then construct a simplified model, M2, by integrating these youngest radiocarbon ages. The posterior PDFs for Events E1, E2, and E3 fall, respectively, between 1636 and 1870 AD, between 1720 and 1923 AD, and between 1849 and 1958 AD (Figure 14a).

\subsubsection{Comparison With the Historical Seismic Catalogue}

We now compare the occurrence of Event Horizons E1, E2, and E3 from our different models with our earthquake catalogue (Table 1), assuming that this catalogue is complete for large and great earthquakes within the period considered. We consider that colluvial wedges only record earthquakes when the site is located within an intensity area MMI $\geq$ VI (Wald et al., 1999). From the historical catalogue, the Mahottari district was only exposed to MMI $\geq \mathrm{VI}$ in $1833 \mathrm{AD}($ Imax-local = VI), in $1866 \mathrm{AD}($ Imax-local $=\mathrm{VI})$, in $1934 \mathrm{AD}$ (Imax-local $\geq$ VIII), and in 1988 AD (Imax-local $=$ VII).

None of these earthquakes are consistent with the solution provided by Model M1: No significant earthquakes are reported between 1510 and $1616 \mathrm{AD}$ (E1) or between 1720 and $1798 \mathrm{AD}$ (E3). Within the period ranging from 1645 to $1729 \mathrm{AD}(\mathrm{E} 2)$, the only potential candidate mentioned in the chronicles is the $1680 \mathrm{AD}$ earthquake. However, this earthquake was not reported in northern India and, therefore, is probably related to a moderate earthquake, with only limited regional impact and no surface ruptures in the Mahottari district.

Model M2 provides a solution in which the dating of earthquake horizons is compatible with historical earthquakes: the 1636-1870 AD period (E1) is broad enough to consider the 1680, 1833, and 1866 AD earthquakes, although the higher probability during the nineteenth century points to the 1833 and $1866 \mathrm{AD}$ events. These two earthquakes are also compatible with the time period defining Earthquake Horizon E2, from 1720 to $1923 \mathrm{AD}$. 
From the trench observation, we know that the earthquake associated with E2 produced surface ruptures, in addition to a large colluvial wedge. Thus, for E2 we can discard the $1866 \mathrm{AD}$ earthquake because this earthquake triggered no significant macroseismic effects and no known surface ruptures in the Mahottari district, although it happened during a rather well-documented period. Similarly, we also discard the 1833 AD earthquake as being E2 because this event is reported with a macroseismic epicenter and a magnitude very similar to the 2015 AD Gorkha earthquake (e.g., Martin et al., 2015), which precludes a rupture at the Charnath outlet. Therefore, no major earthquake could be obviously linked to E2 and, thus to E1, during the nineteenth century. Conversely, we suggest that the only large earthquake that could be reasonably associated with E2 is the only large earthquake in the early twentieth century in this area, the 1934 Bihar-Nepal earthquake.

5.1.4. Testing the Signature of the 1934 AD Earthquake for a Surface Rupture at Charnath Khola As previously mentioned, E2, the main earthquake horizon in the trench, is associated with a surface rupture along the F3 and F4 fault splays. This rupture contributed to the significant drag-folding of CW2 and to the offset of the Siwalik SW2 above CW2. Although this motion was most probably accompanied by a significant rupture in $\mathrm{F} 1$, this cannot be ascertained so far, given the limited availability of young charcoal samples predating the last rupture in F1 (i.e., the youngest deposits dated beneath it are more than 8,000 years old, and the fault zone is sealed by a channel dated at 1962 AD). According to Models M1 and M2, this earthquake horizon, E2, should be dated sometime between 1645 and 1923 AD.

These models are, however, biased by the simplistic assumptions that we considered: Model M1 neglects the inbuilt age, transport and reworking time lags, while M2 minimizes them by taking the youngest ages in every unit. In both models, the radiocarbon dates of the detrital charcoals are necessarily older than the actual deposition ages (e.g., Bollinger et al., 2016; Dezileau et al., 2014; Gavin, 2001) and bias the results, forcing Earthquake Horizon E2 to seem older than it really is. In fact, the charcoal sample dates found in the upper to post earthquake units, as well as the ages found in Wedge CW1-a, could be compatible with E2 being the $1934 \mathrm{AD}$ earthquake. In addition, the fact that 3 to $5 \mathrm{~m}$ of sediments seal the earthquake horizon and were deposited slightly before $1962 \mathrm{AD}$ (CO09-185) appears reasonable, given the location of the units at the toe of the scarp.

We therefore check whether the 1934 Bihar-Nepal earthquake could be associated with the surface rupturing Earthquake Horizon E2, by performing a Bayesian analysis where we fixed a priori the specific date of 1934 AD in Models M1 and M2. The posterior age distribution calculated for the samples collected in Units CW1a, u2, and CW1-b reproduces this scenario, even when no inbuilt, transport or reworking are considered (Figures 13b and 14b). Associating the $1934 \mathrm{AD}$ earthquake with the last surface rupture found in the Cobra trench is therefore possible. We believe this to be the most credible scenario, given the present historical earthquake knowledge. A reasonable total time lag of a few decades between the radiocarbon age and the deposition of the sedimentary units in the trench does help in matching the detrital charcoal age distribution.

This suggests that dating earthquake horizons through the calibration and Bayesian modelling of these ${ }^{14} \mathrm{C}$ ages, assuming very conservative priors (no inbuilt, transport, and reworking), can then lead to predating the true age of earthquake occurrence by several decades. Hence, dates of paleoearthquakes should be considered with caution, especially when the radiocarbon dates fall within periods with a flat calibration curve. This effect is likely to be emphasized when the number of dates is small, hindering a good assessment of the different biases affecting the ${ }^{14} \mathrm{C}$ dates.

\subsection{Recording of Past Earthquakes in the Cobra Trench}

The colluvial wedge CW2 could be produced by strong shaking associated with the 1833 or 1866 AD remote earthquakes, without surface rupture on the Charnath Khola. We demonstrated that the most recent surface rupture is likely related to the 1934 Bihar-Nepal earthquake. Along Faults F3 and F4, our paleoseismic observations suggest that the coseismic slip was greater than $2 \mathrm{~m}$, although the respective contribution of the splay faults to the scarp growth remain unquantified, since the scarplets formed at the surface were eroded prior to the deposition of the fluvial sands (u2). Along F1, the intense shearing in the fault zone up to the surface and the amplitude of the coseismic slip related to the last earthquake could not be properly estimated in our trench. However, we observed in the morphology a 1- to 3-m high step, which marks the base of the cumulative escarpment (Figures $4 \mathrm{~d}$ and 6). This step is located where Fault F1 reaches the surface. We therefore propose that this young topographic feature results from the activation of the fault zone F1 during the 1934 earthquake. We estimate that the apparent vertical offset there is related to an 
amount of dip slip displacement of between 1.3 and $6.5 \mathrm{~m}$ (F1 dips 35 to $50^{\circ} \mathrm{N}$ ). The total coseismic slip in the $\mathrm{F} 1, \mathrm{~F} 3$, and F4 faults therefore reached a minimum value between 3.3 and $8.5 \mathrm{~m}$. In addition, the deposition of colluvial wedge CW1-a is likely related to the activation of Fault F1 during the 1934 AD earthquake, as the radiocarbon dates sampled in this colluvial wedge are consistent with its emplacement soon after 1934 AD.

However, given our stratigraphic and chronological constraints, it is difficult to associate the deposition of colluvial wedge CW1-b with strong shakings between 1935 and 1954 AD, a period devoid of any large instrumental earthquakes in central Nepal. If one assumes a time lag in radiocarbon dates of a few decades, the association of this colluvial wedge with the $1988 \mathrm{AD}$ earthquake could be possible. However, this is not our preferred scenario, since we noticed very little changes in local morphology between the first aerial photographs in 1964, and the present-day satellite images suggesting that much of the scarp degradation happened before 1964. We suspect instead that the colluvial wedge may rather correspond to limited episodes of the 1934 free-face scarp degradation during extreme weathering events (heavy rain during the monsoon), limiting the total number of wedges associated with earthquakes to two.

This observation demonstrates that colluvial wedges along the Main Frontal thrust are not necessarily triggered by strong ground motion and that a systematic identification of a wedge with an earthquake could lead to overestimating the actual number of earthquakes.

\subsection{Aggradation Following Great Earthquakes and Their Implications for the Quantification of the Coseismic Uplift}

The sedimentary records associated with the largest earthquakes having happened along mountain ranges may provide an additional source of chronological bias. Indeed, these events trigger numerous landslides that contribute to catastrophic valley infills (e.g., Kargel et al., 2016; Korup, 2005; Korup et al., 2004; Parker et al., 2011; Schwanghart et al., 2016; Stolle et al., 2017; Yanites et al., 2010). In the case of the Himalayan front, the excess of sediments brought to the watersheds is flushed out by rivers and deposited partly along the MFT, both in the hanging and foot walls, leading to the deposition and abandonment of fluvial terraces. During these postearthquake processes, sediments already stored in the hanging wall terraces could also be partly remobilized. These sediments contain detrital charcoals with radiocarbon ages that necessarily predate the earthquake. These charcoal samples are transported and deposited during the post earthquake aggradation phase within postearthquake units, on top of the last surface rupture.

In $1934 \mathrm{AD}$, the watershed of the Charnath Khola and its vicinity were particularly affected by catastrophic landslides and rock falls (Rana, 1935). Hence, the fluvial sequences (4 to $5 \mathrm{~m}$ ) deposited on top of the last surface rupture at Charnath Khola represent a direct sedimentological record of the landslide-sediment pulses that followed the 1934 Bihar-Nepal earthquake, locally complemented by scarp degradation. This scenario is consistent with the modern radiocarbon dates collected in post-earthquake Units CW1-b and $\mathrm{u} 2$, showing that these top 1.8-m thick deposits resulted from an aggradation process that occurred after $1954 \mathrm{AD}$ and prior to $1964 \mathrm{AD}$ (date of aerial photographs), in less than 10 years.

Following the 1934 event, earthquake-triggered aggradation may have been great enough to reach the altitude of T2. Subsequent abandonment of Pal-T2 might be related to such a large aggradation that finally clogged the Pal-T2 channel and promoted relocation of the Charnath Khola into its current location. The main aggradation episode lasted less than 30 years, as attested by the observation that the Pal-T2 channel was already abandoned in 1964, the date of acquisition of the earliest aerial photographs accessed in our study. This is also consistent with the age distribution of the fluvial sands found in the trench Unit $u 2$, which were dated between 1957 (CO09-159) and 1963 AD (CO09-142). In this trench, the modern detrital charcoals further helped to constrain the aggradation rates following the $1934 \mathrm{AD}$ earthquake. Indeed, almost $1 \mathrm{~m}$ of sediment accumulated between the deposition of CO09-83 and CO09-36 (dated at 1954 AD) and the deposition of CO09-185 (dated at 1962 or 1980 AD). It corresponds to a mean aggradation rate estimated at between 2.1 and $3.1 \mathrm{~cm} /$ year. The aggradation rate was even larger $(\sim 11.5 \mathrm{~cm} /$ year $)$ between 1934AD and the 1950s, with at least $3 \mathrm{~m}$ of sediments being deposited above the earthquake horizon. This aggradation episode was then followed by the abandonment of the T2 treads and by $5 \mathrm{~m}$ of incision down to the present-day riverbed (see the elevation of T2 above the Charnath riverbed; Figures $6 \mathrm{~b}$ and 11).

A similar aggradation episode was probably responsible for the filling of the Pal-T4 paleomeander, and we propose that this terrace tread was abandoned after the thirteenth century, according to the detrital 
charcoal sampled within the pebble-gravels. Taking the historical earthquake catalogue, this aggradation/incision episode could be related to the devastating $1255 \mathrm{AD}$ earthquake (Pant, 2002). The $1934 \mathrm{AD}$ earthquake would have then brought the meander Pal-T4 definitively above the highest flood levels, more than $\sim 15$-m above the present bed of the Charnath Khola. The remains of the Pal-T4 terrace tread were therefore probably preserved from the effects of both the 1255 and 1934 AD earthquakes.

From our mapping and topographic profiles, Pal-T4 presents an apparent vertical offset of $14 \pm 3 \mathrm{~m}$ across the MFT and it also stands $15-\mathrm{m}$ above the T2 level (Figure 11). This vertical cumulative offset probably results from the coseismic motion of the 1934 and $1255 \mathrm{AD}$ earthquakes. It would correspond to a cumulative dip slip of $18-24.5 \mathrm{~m}$, assuming a thrust angle of $35^{\circ}-50^{\circ}$. This leads to an amount of slip between 9 and $12 \mathrm{~m}$ per event, considering that both earthquakes were similar. This value is consistent with previous estimates of the coseismic slip accommodated by major paleoearthquakes along the MFT (Bollinger et al., 2014; Lavé et al., 2005; Wesnousky, Kumahara, Chamlagain, Pierce, Karki, et al., 2017). No coeval terrace treads were preserved in both walls of the MFT after the 1934 AD earthquake, and therefore, we cannot estimate the apparent vertical offset associated with the 1934 earthquake from our topographic profiles. However, on the western wall of the trench, we estimate a minimum slip of $2 \mathrm{~m}$ taken up by F3 and F4 during the 1934 AD earthquake. This minimum amount of coseismic slip was probably complemented by a dip slip displacement of 3.3 to $6.5 \mathrm{~m}$ on Fault F1, a value consistent with the 1- to-3-m high scarp found at the toe of the cumulative escarpment (Figures $4 \mathrm{~d}$ and 6 ).

\section{Conclusions}

Our study in the Cobra trench shows unambiguously that the Mw8.3, 1934AD, earthquake ruptured the surface along an active fault strand of the MFT at the Charnath Khola outlet. This surface rupture, with more than 5.3-8.5 m of coseismic offset, was followed after the earthquake by the deposition of 4 to $5 \mathrm{~m}$ of fluvial sediments interfingered with a massive colluvial wedge in the footwall of the main fault scarp. The two additional colluvial wedges observed in the trench, which remain unassociated with demonstrated surface faulting, may be related to the strong shaking associated with the 1833/1866 AD events (CW2) and possibly with the $1988 \mathrm{AD}$ events (CW1b). Alternatively, these wedges might also be due to erosion of the cumulated seismic scarp during some severe weather episode. Detailed examination of the sedimentological environment and radiocarbon ages of more than 50 detrital charcoal samples straddling the earthquake horizon highlights the fact that the use of radiocarbon age in paleoseismic investigations without any consideration of potential biases may result in artificially aging the deposition ages of the sediment. This implies that some of the event horizons already dated are possibly more recent than previously thought, advocating for a systematic revisit of correlations between paleoseismological earthquakes identified in trenches and historical earthquakes.

Our detailed investigations in Charnath Khola also show that fluvial terraces in the hanging wall of the MFT, at the outlet of rivers draining large watersheds, are not always abandoned immediately after the surface rupture. Indeed, our paleoseismic observations show that the historical Bihar-Nepal earthquake was followed by an episode of aggradation locally reaching 4 to $5 \mathrm{~m}$, which eventually led to the abandonment of a river terrace (Pal-T2 in the hanging wall, $\mathrm{T} 2$ in the footwall). Both the observations on the western riverbank and in the trench demonstrate that most of the sediments, which now overlap the primary surface ruptures, were deposited within 30 years from the great $1934 \mathrm{AD}$ earthquake and that most of the incision following the earthquake happened within this same period. Similarly, the radiocarbon ages of the detrital charcoals sampled within the top of the previous generation of fluvial terraces abandoned suggest that the historical $1255 \mathrm{AD}$ earthquake could be responsible for the aggradation and then abandonment of Paleomeander Pal-T4, which marks the hanging wall more than $15 \mathrm{~m}$ above the current Charnath Khola riverbed.

The time period between the earthquake rupture and the terrace tread abandonment probably depends on the amount of earthquake-induced sediments made available by mass-wasting processes in the hanging wall of the thrust, as well as on the capacity of the river for deposition and incision. The future challenges in such environments will be to determine this time period (a period found here to be shorter than 30 years for a $40 \mathrm{~km}^{2}$ watershed), as well as to measure the total amount of material deposited during the post-earthquake aggradation phase. This is needed to refine the date of occurrence, as well as to better estimate the amount of tectonic uplift accommodated by devastating paleoearthquakes and historical earthquakes along the MFT. 


\section{Acknowledgments}

We thank the Earth Observatory of Singapore for financial support, as well as the National Research Foundation Singapore and the Singapore Ministry of Education under the Research Centers of Excellence initiative. We are grateful to the Department of Mines and Geology in Kathmandu, Nepal, for organizing the fieldwork. DASE-France and IPGP are also thanked for their contribution through the organization and funding of S. N. S.'s thesis, from which part of this work is derived. Two anonymous reviewers provided constructive comments that helped to improve the original manuscript. The data used in this study can be found in the tables and supporting information files.

\section{References}

Ader, T., Avouac, J.-P., Liu-Zeng, J., Lyon-Caen, H., Bollinger, L., Galetzka, J., et al. (2012). Convergence rate across the Nepal Himalaya and interseismic coupling on the Main Himalayan Thrust: Implications for seismic hazard. Journal of Geophysical Research, 117, B04403. https://doi.org/10.1029/2011JB009071

Adhikari, L. B., Gautam, U. P., Koirala, B. P., Bhattarai, M., Kandel, T., Gupta, R. M., et al. (2015). The aftershock sequence of the 2015 April 25 Gorkha-Nepal earthquake. Geophysical Journal International, 203(3), 2119-2124. https://doi.org/10.1093/gii/ggv412

Ambraseys, N. N., \& Douglas, J. (2004). Magnitude calibration of north Indian earthquakes. Geophysical Journal International, 159(1), 165-206. https://doi.org/10.1111/j.1365-246X.2004.02323.X

Atwater, B. F. (1990). 15. ALLUVIAL PLAINS AND EARTHQUAKE RECURRENCE AT. US Geological Survey Professional Paper, 1487, 273.

Avouac, J.-P., Meng, L., Wei, S., Wang, T., \& Ampuero, J.-P. (2015). Lower edge of locked Main Himalayan Thrust unzipped by the 2015 Gorkha earthquake. Nature Geoscience, 8(9), 708-711. https://doi.org/10.1038/ngeo2518

Bilham, R. (1995). Location and magnitude of the 1833 Nepal earthquake and its relation to the rupture zones of contiguous great Himalayan earthquakes. Current Science, 69, 101-128.

Bilham, R. (2019). Himalayan earthquakes: A review of historical seismicity and early 21st century slip potential. Geological Society, London, Special Publications, 483, SP483-SP416.

Bilham, R., Blume, F., Bendick, R., \& Gaur, V. K. (1998). Geodetic constraints on the translation and deformation of India: Implications for future great Himalayan earthquakes. Current Science, 74(3), 213-229.

Bilham, R., \& Wallace, K. (2005). Future $M w>8$ earthquakes in the Himalaya: Implications from the 26 Dec $2004 M w=9.0$ earthquake on India's eastern plate margin. Geological Survey of India Special Publication, 85, 1-14.

Bollinger, L., Sapkota, S. N., Tapponnier, P., Klinger, Y., Rizza, M., van der Woerd, J., et al. (2014). Estimating the return times of great Himalayan earthquakes in eastern Nepal: Evidence from the Patu and Bardibas strands of the Main Frontal Thrust. Journal of Geophysical Research: Solid Earth, 119, 7123-7163. https://doi.org/10.1002/2014JB010970

Bollinger, L., Tapponnier, P., Sapkota, S. N., \& Klinger, Y. (2016). Slip deficit in central Nepal: Omen for a repeat of the 1344AD earthquake? Earth, Planets and Space, 68(1), 12. https://doi.org/10.1186/s40623-016-0389-1

Bomford, G.. (1937), Leveling in Bengal and Bihar, in Survey of IndiaGeodetic Report 1936, edited by H.J. Couchman, pp. 93-97, Geodetic branchSurvey of India, Dehra Dun.

Bronk Ramsey, C. (2008). Deposition models for chronological record. Quaternary Science Reviews, 27(1-2), 42-60. https://doi.org/10.1016/ j.quascirev.2007.01.019

Bronk Ramsey, C. (2013). OxCal. https://c14.arch.ox.ac.uk/oxcal.html

Campbell, A. (1833). Account of the earthquake at Kathmandu. Journal of the Asiatic Society of Bengal, 2, 564-567.

Delcaillau, B. (1992). Les Siwaliks du Nëpal Oriental, Presses du CNRS, 1-205, Paris,France.

Dezileau, L., Terrier, B., Berger, J. F., Blanchemanche, P., Latapie, A., Freydier, R., et al. (2014). A multidating approach applied to historical slackwater flood deposits of the Gardon River, SE France. Geomorphology, 214, 56-68. https://doi.org/10.1016/j.geomorph.2014.03.017

Dixit, A. M. (1991). Geological effects and intensity distribution of the Udayapur (Nepal) earthquake of August 20, 1988. Journal of NGS (Nepal Geological Society), 7, 1-17.

Gavin, D. G. (2001). Estimation of inbuilt age in radiocarbon ages of soil charcoal for fire history studies. Radiocarbon, 43(1), 27-44. https:// doi.org/10.1017/S003382220003160X

Grandin, R., Vallée, M., Satriano, C., Lacassin, R., Klinger, Y., Simoes, M., \& Bollinger, L. (2015). Rupture process of the $M w=7.92015$ Gorkha earthquake (Nepal): Insights into Himalayan megathrust segmentation. Geophysical Research Letters, 42, 8373-8382. https://doi. org/10.1002/2015GL066044

Graveleau, F., Strak, V., Dominguez, S., Malavieille, J., Chatton, M., Manighetti, I., \& Petit, C., 2015. Experimental modelling of tectonicserosion-sedimentation interactions in compressional, extensional, and strike-slip settings. Geomorphology, Laboratory Experiments in Geomorphology 46th Annual Binghamton Geomorphology Symposium 18-20 September 2015 244, 146-168. https://doi.org/10.1016/j. geomorph.2015.02.011

Hossler, T., Bollinger, L., Sapkota, S. N., Lavé, J., Gupta, R. M., \& Kandel, T. P. (2016). Surface ruptures of large Himalayan earthquakes in Western Nepal: Evidence along a reactivated strand of the Main Boundary Thrust. Earth and Planetary Science Letters, 434, 187-196. https://doi.org/10.1016/j.epsl.2015.11.042

Hua, Q., \& Barbetti, M. (2004). Review of tropospheric bomb C-14 datafor carbon cycle modeling and age calibration purposes, Radiocarbon, 46,1273-1298.

Kargel, J. S., Leonard, G. J., Shugar, D. H., Haritashya, U. K., Bevington, A., Fielding, E. J., et al. (2016). Geomorphic and geologic controls of geohazards induced by Nepal's 2015 Gorkha earthquake. Science, 351, aac8353. https://doi.org/10.1126/science.aac8353

Korup, O. (2005). Large landslides and their effect on sediment flux in South Westland, New Zealand. Earth Surface Processes and Landforms, 30(3), 305-323. https://doi.org/10.1002/esp.1143

Kumar, S., Wesnousky, S. G., Rockwell, T. K., Briggs, R. W., Thakur, V. C., \& Jayangondaperumal, R. (2006). Paleoseismic evidence of great surface rupture earthquakes along the IndianHimalaya. Journal of Geophysical Research, 111, B03304.

Kumar, S.,Wesnousky, S. G., Jayangondaperumal, R., Nakata, T., Kumahara, Y., \& Singh, V. (2010). Paleoseismological evidence of surface faulting along thenortheastern Himalayan front, India: Timing, size, and spatial extent of greatearthquakes. Journal of Geophysical Research, 115(B12).

Korup, O., McSaveney, M. J., \& Davies, T. R. H. (2004). Sediment generation and delivery from large historic landslides in the Southern Alps, New Zealand. Geomorphology, 61(1-2), 189-207. https://doi.org/10.1016/j.geomorph.2004.01.001

Lavé, J., \& Avouac, J. P. (2000). Active folding of fluvial terraces across the Siwaliks Hills, Himalayas of central Nepal. Journal of Geophysical Research, 105(B3), 5735-5770. https://doi.org/10.1029/1999JB900292

Lavé, J., Yule, D., Sapkota, S., Basant, K., Madden, C., Attal, M., \& Pandey, R. (2005). Evidence for a Great Medieval Earthquake ( 1100 A.D.) in the Central Himalayas, Nepal. Science, 307(5713), 1302-1305. https://doi.org/10.1126/science.1104804

Le Roux-Mallouf, R., Ferry, M., Ritz, J.-F., Berthet, T., Cattin, R., \& Drukpa, D. (2016). First paleoseismic evidence for great surfacerupturing earthquakes in the Bhutan Himalayas. Journal of Geophysical Research: Solid Earth, 121, 7271-7283. https://doi.org/10.1002/ 2015JB012733

Lettis, W. R., Wells, D. L., \& Baldwin, J. N. (1997). Empirical observations regarding reverse earthquakes, blind thrust faults, and quaternary deformation: Are blind thrust faults truly blind? Bulletin of the Seismological Society of America, 87, 1171-1198.

McCalpin, J. P. (2009). Paleoseismology (Vol. 95). Academicpress. 
Martin, S., \& Szeliga, W. (2010). A catalog of felt intensity data for 570 earthquakes in India from 1636 to 2009. Bulletin of the Seismological Society of America, 100(2), 562-569. https://doi.org/10.1785/0120080328

Malik, J. N., Sahoo, A. K., Shah, A. A., Shinde, D. P., Juyal, N., \& Singhvi, A. K. (2010). Paleoseismic evidence from trench investigation along Hajipur fault, Himalayan Frontal Thrust, NW Himalaya: implications of the faulting pattern onlandscape evolution and seismic hazard. Journal of structural geology, 32(3), 350-361.

Martin, S. S., Hough, S. E., \& Hung, C. (2015). Ground motions from the $2015 \mathrm{Mw} 7.8$ Gorkha, Nepal, earthquake constrained by a detailed assessment of macroseismic data. Seismological Research Letters, 86(6), 1524-1532. https://doi.org/10.1785/0220150138

Meunier, P., Hovius, N., \& Haines, A. J. (2007). Regional patterns of earthquake-triggered landslides and their relation to ground motion. Geophysical Research Letters, 34, L20408. https://doi.org/10.1029/2007GL031337

Molnar, P., \& Qidong, D. (1984) Faulting associated with large earthquakes and the average rate of deformation in central and eastern Asia Journal of Geophysical Research, 89(B7), 6203-6227.

Molnar, P., \& Pandey, M. R. (1989). Rupture zones of great earthquakes in the Himalayan region. Proceedings of the Indian Academy of Sciences - Earth \& Planetary Sciences, 98, 61-70. https://doi.org/10.1007/BF02880376

Mugnier, J.-L., Gajurel, A., Huyghe, P., Jayangondaperumal, R., Jouanne, F., \& Upreti, B. (2013). Structural interpretation of the great earthquakes of the last millennium in the central Himalaya. Earth Science Reviews, 127, 30-47. https://doi.org/10.1016/j. earscirev.2013.09.003

Nakata, T. (1989). Active faults of the Himalaya of India and Nepal, Geological Society of America Special Papers, (pp. 243-264). America: Geological Society. https://doi.org/10.1130/SPE232-p243

Oldham, T. (1883). In R. D. Oldham (Ed.), A catalogue of Indian earthquakes, Mem. Geol. Surv. India (Vol. 19, pp. 163-215).

Pant, M. R. (2002). A step toward a historical seismicity of Nepal. Adarsa, 2, 29-60.

Parker, R. N., Densmore, A. L., Rosser, N. J., de Michele, M., Li, Y., Huang, R., et al. (2011). Mass wasting triggered by the 2008 Wenchuan earthquake is greater than orogenic growth. Nature Geoscience, 4(7), 449-452. https://doi.org/10.1038/ngeo1154

Pradhan, U. M. S., Shrestha, R. B., \& KC SB, S. S. (2004). Geological map of petroleumexploration block-8, Janakpur, Central Nepal (Scale: 1: 250,000). Petroleum Exploration Promotion Project, Department of Mines and Geology, Kathmandu.

Prajapati, S. K., Dadhich, H. K., \& Chopra, S. (2017). Isoseismal map of the 2015 Nepal earthquake and its relationships with groundmotion parameters, distance and magnitude. Journal of Asian Earth Sciences, 133, 24-37.

Rajendran, C. P., John, B., \& Rajendran, K. (2015). Medieval pulse of great earthquakes in the central Himalaya: Viewing past activities on the frontal thrust. Journal of Geophysical Research: Solid Earth, 120, 1623-1641. https://doi.org/10.1002/2014JB011015

Rana, B. S., (1935). Maha Bhukampa, Bahane Mahal BS 1992, Kathmandu, 1-250.

Reimer, P. J., Bard, E., Bayliss, A., Beck, J. W., Blackwell, P. G., Ramsey, C. B., et al. (2013). IntCal13 and Marine13 Radiocarbon Age Calibration Curves 0-50,000 years cal BP. Radiocarbon, 55(4), 1869-1887. https://doi.org/10.2458/azu_js_rc.55.16947

Roy, S. C. (1939). The Bihar-Nepal earthquake of 1934 by officers of the geological survey of India. Memoirs - Geological Survey of India, $73,417$.

Sapkota, S. N. (2011). Surface rupture of 1934 Bihar-Nepal earthquake: Implications for seismic hazard in Nepal Himalaya (Doctoral dissertation, Institut de physique du globe, Paris). https://www.theses.fr/2011GLOB0012

Sapkota, S. N., Bollinger, L., Klinger, Y., Tapponnier, P., Gaudemer, Y., \& Tiwari, D. (2013). Primary surface ruptures of the great Himalayan earthquakes in 1934 and 1255. Nature Geoscience, 6(1), 71-76. https://doi.org/10.1038/ngeo1669

Sapkota, S. N., Bollinger, L., \& Perrier, F. (2016). Fatality rates of the Mw $\sim 8.2,1934$, Bihar-Nepal earthquake and comparison with the April 2015 Gorkha earthquake. Earth, Planets and Space, 68(1), 40. https://doi.org/10.1186/s40623-016-0416-2

Schwanghart, W., Bernhardt, A., Stolle, A., Hoelzmann, P., Adhikari, B. R., Andermann, C., et al. (2016). Repeated catastrophic valley infill following medieval earthquakes in the Nepal Himalaya. Science, 351(6269), 147-150. https://doi.org/10.1126/science.aac9865

Stolle, A., Bernhardt, A., Schwanghart, W., Hoelzmann, P., Adhikari, B. R., Fort, M., \& Korup, O. (2017). Catastrophic valley fills record large Himalayan earthquakes, Pokhara, Nepal. Quaternary Science Reviews, 177, 88-103. https://doi.org/10.1016/j.quascirev.2017.10.015

Szeliga, W., Hough, S., Martin, S., \& Bilham, R. (2010). Intensity, magnitude, location, and attenuation in India for felt earthquakes since 1762. Bulletin of the Seismological Society of America, 100(2), 570-584. https://doi.org/10.1785/0120080329

Upreti, B. N., Nakata, T., Kumahara, Y., Yagi, H., Okumura, K., Rockwell, T. K., et al., (2000). The latest active faulting in southeast Nepal. In Proceedings of the Hokudan International symposium and School in active faulting (pp. 533-536). Hyogo Japan: Awaji Island.

Vermeesch, P. (2012). On the visualisation of detrital age distributions. Chemical Geology, 312-313, 190-194. https://doi.org/10.1016/j. chemgeo.2012.04.021

Wald, D. J., Quitoriano, V., Heaton, T. H., \& Kanamori, H. (1999). Relationships between peak ground acceleration, peak ground velocity, and modified Mercalli intensity in California. Earthquake Spectra, 15(3), 557-564. https://doi.org/10.1193/1.1586058

Wesnousky, S. G., Kumahara, Y., Chamlagain, D., Pierce, I. K., Karki, A., \& Gautam, D. (2017). Geological observations on large earthquakes along the Himalayan frontal fault near Kathmandu, Nepal. Earth and Planetary Science Letters, 457, 366-375. https://doi.org/ 10.1016/j.epsl.2016.10.006

Wesnousky, S. G., Kumahara, Y., Chamlagain, D., Pierce, I. K., Reedy, T., Angster, S. J., \& Giri, B. (2017). Large paleoearthquake timing and displacement near Damak in eastern Nepal on the Himalayan Frontal Thrust: Paleoearthquake in Eastern Nepal. Geophysical Research Letters, 44, 8219-8226. https://doi.org/10.1002/2017GL074270

Wesnousky, S. G., Yasuhiro, K., Takashi, N., Deepak, C., \& Prajwol, N. (2018). New observations disagree with previous interpretations of surface rupture along the Himalayan frontal thrust during the great 1934 Bihar-Nepal earthquake. Geophysical Research Letters, 45 , 2652-2658. https://doi.org/10.1002/2018GL077035

Yanites, B. J., Tucker, G. E., Mueller, K. J., \& Chen, Y.-G. (2010). How rivers react to large earthquakes: Evidence from central Taiwan. Geology, 38(7), 639-642. https://doi.org/10.1130/G30883.1

\section{References From the Supporting Information}

Axelsson, P. (2000). DEM generation from laser scanner data using adaptive TIN models. The International Archives of Photogrammetry and Remote Sensing, 33(B4/1), 110-117.

Ussyshkin, R. V., \& Smith, B. (2006). Performance analysis of ALTM3100EA: Instrument specifications and accuracy of LIDAR data. The International Archives of the Photogrammetry, Remote Sensing and Spatial Information Sciences, 34, 1-7. 